\title{
Practical considerations for choosing a mouse model of Alzheimer's disease
}

\author{
Joanna L. Jankowsky ${ }^{1,2,3,4,5^{*}}$ and Hui Zheng ${ }^{1,4,5,6^{*}}$
}

\begin{abstract}
Alzheimer's disease (AD) is behaviorally identified by progressive memory impairment and pathologically characterized by the triad of $\beta$-amyloid plaques, neurofibrillary tangles, and neurodegeneration. Genetic mutations and risk factors have been identified that are either causal or modify the disease progression. These genetic and pathological features serve as basis for the creation and validation of mouse models of AD. Efforts made in the past quarter-century have produced over 100 genetically engineered mouse lines that recapitulate some aspects of AD clinicopathology. These models have been valuable resources for understanding genetic interactions that contribute to disease and cellular reactions that are engaged in response. Here we focus on mouse models that have been widely used stalwarts of the field or that are recently developed bellwethers of the future. Rather than providing a summary of each model, we endeavor to compare and contrast the genetic approaches employed and to discuss their respective advantages and limitations. We offer a critical account of the variables which may contribute to inconsistent findings and the factors that should be considered when choosing a model and interpreting the results. We hope to present an insightful review of current AD mouse models and to provide a practical guide for selecting models best matched to the experimental question at hand.
\end{abstract}

Keywords: Transgenic mouse, Knockout, Knock-in, Amyloid precursor protein, APP, Aß, Tau, MAPT, TREM2, Apolipoprotein E, ApoE

\section{Background}

Alzheimer's disease $(\mathrm{AD})$ is the most common form of ageassociated neurodegenerative disorder clinically characterized by a decline in cognitive function and pathologically defined by the accumulation of extracellular $\beta$-amyloid $(\mathrm{A} \beta)$ plaques and intracellular neurofibrillary tangles (NFTs). Plaque $A \beta$ peptide of 40 or 42 amino acids is produced by proteolytic cleavage of the amyloid precursor protein (APP) (Fig. 1), while NFTs are composed of hyperphosphorylated and misfolded tau protein. These neuropathological hallmarks are accompanied by profound neuroinflammation marked by astrocytic and microglial activation. A small percentage of $\mathrm{AD}$ cases are caused by genetic mutations in APP and presenilins identified in familial AD (FAD), where these mutations alter APP processing in favor of $A \beta 42$ to drive the peptide aggregation thought to initiate disease. These genetic, biochemical, and neuropathological features form the basis for creating and validating animal models of

\footnotetext{
* Correspondence: jankowsk@bcm.edu; huiz@bcm.edu

${ }^{1}$ Department of Neuroscience, Baylor College of Medicine, Houston, TX 77030, USA

Full list of author information is available at the end of the article
}

AD. Beyond the autosomal dominant FAD mutations, the apolipoprotein E $\varepsilon 4$ allele (APOE $\varepsilon 4$ ), along with rare point mutations in the triggering receptor expressed on myeloid cells 2 (TREM2), are strong risk factors for the more common sporadic, late-onset AD (LOAD).

Animal models are critical for understanding disease pathogenesis and also serve as valuable tools for preclinical testing. One of the most important considerations in working with rodent models is matching the mouse (or rat) to the experimental question under study. There are more than 100 different genetically engineered mouse lines reported to capture some aspect of AD - so many that it has become impossible to exhaustively track them all. We focus here on models that have been widely used and which remain available either privately or publically. We also highlight newly created lines that may be useful in modeling LOAD. The unavoidable first step in deciding among them is delineating the experimental question to be asked. Existing mouse models recapitulate amyloid plaques, neurofibrillary tangles, or neurodegeneration, 


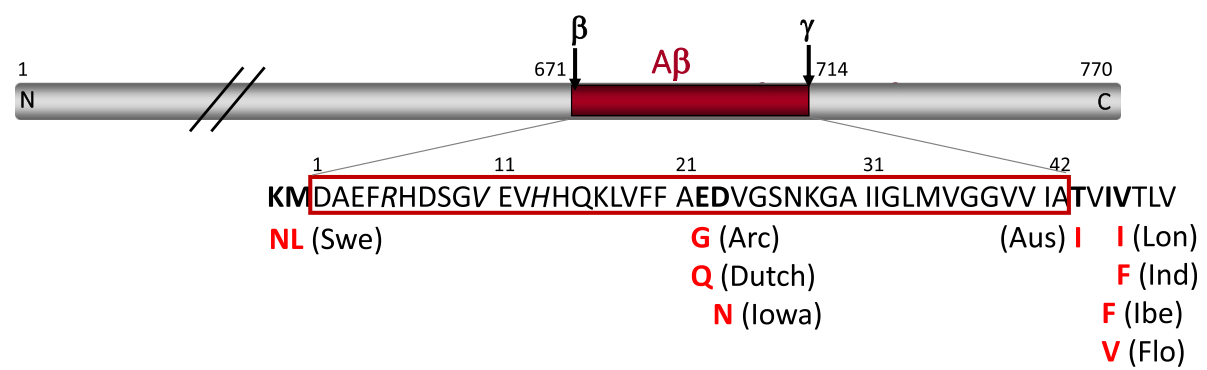

Fig. 1 Diagram of APP illustrating nine FAD mutations that have been incorporated into mouse models. The A 3 domain is highlighted in red, with the $\beta$ - and $\gamma$-cleavage sites identified at residues 671 and 714 , respectively, using the numbering convention for full-length 770 amino acid protein. The amino acid sequence of $A \beta$ is outlined in red, with the positions of several commonly used FAD mutations and their amino acid substitutions shown (in bold) alongside the geographic name identifying each variant. Italic residues indicate the three sites at which the $A \beta$ sequence diverges between human and mouse (human is shown). Swe, Swedish; Arc, Arctic; Aus, Austrian; Lon, London; Ind, Indiana; Ibe, Iberian; Flo, Florida

but generally not all in the same mouse. Some models develop these hallmarks rapidly, others more authentically retain the aging facet of the disease. This review will describe key factors to consider when choosing between models, but you must know which features are essential for testing your hypothesis, as well as which are expendable. No mouse model is a faithful reproduction of human $\mathrm{AD}$, but they can be useful tools when appropriately matched to the experimental question of interest.

\section{Matching your model to your experimental question - what is it that you want to study?}

A myriad of models is at your fingertips. Most of them were designed to capture some aspect of disease pathology - and primarily plaques or tangles - with degeneration and cognitive decline emerging in some as serendipitous benefits. Choosing among them requires knowing what features of $\mathrm{AD}$ are required for your particular experiment, and so we describe below the main strategies that have been used to model these pathologies in genetically engineered mice.

\section{Amyloid plaques and CAA}

Amyloid plaques and cerebral amyloid angiopathy (CAA) both arise as insoluble deposits of the amyloid $\beta$ peptide $(A \beta)$. This peptide is derived by sequential cleavage of the amyloid precursor protein (APP) by the $\beta$-APP cleaving enzyme (BACE1) and $\gamma$-secretase at $\mathrm{N}$ - and C-termini respectively, to release three protein fragments: soluble APP (sAPP) and A $\beta$ into the extracellular space and the amyloid-intracellular domain (AICD) into the cytoplasm. Mutations in APP were the first causes of early-onset FAD to be identified [1]; these autosomal dominant mutations tend to cluster around the $\beta$ - and $\gamma$ - processing sites to affect $A \beta$ production. Transgenic expression of familial APP mutations provided the first successful means of reproducing amyloid pathology in mice [2] (Table 1); since then many dozen lines of APP-transgenic and knock-in have been created and characterized. Because amyloid deposition is time- and concentration-dependent, achieving pathology within the mouse lifespan requires that the production of $A \beta$ be dramatically elevated relative to endogenous. This is most often accomplished by overexpressing human APP harboring one or more point mutations identified from FAD (Fig. 1). The Swedish mutation is most commonly used for this purpose (Swe), and is based on a two amino acid substitution adjacent to $\beta$-secretase cleavage at the N-terminus of A $\beta$ [3]. The Swe mutation increases APP processing through the $\beta$-secretase pathway, thereby elevating production of $A \beta$ relative to wild-type [4].

Additional mutations may also be incorporated at the $\gamma$ secretase $C$-terminus of $A \beta$ to elevate the ratio of $A \beta 42$ relative to the predominant but less aggregation-prone $A \beta 40$. Several familial C-terminal mutations have been used in mouse models including those identified from Indiana (Ind, V717F [5]), London (Lon, V717I [1], Florida (Flo, I716V [6]) and the Iberian Peninsula (Ibe, I716F [7]). By elevating the ratio of $A \beta 42: 40$, these $C$-terminal mutations enhance $A \beta$ aggregation and accelerate the formation of amyloid plaques to produce early onset pathology. Plaque onset can also be accelerated through familial mutations in presenilin 1 (PSEN1), such as M146V [8], M146L [9], L166P [10], L286V [8], or exon 9 deletion (dE9 [11]) (see http://www.alzforum.org/mutations for details). These PSEN1 mutations shift APP processing by $\gamma$-secretase to produce longer, more pathogenic $A \beta$ peptides which are useful for accelerating disease in short-lived animal models.

A handful of models also include APP mutations within the central $A \beta$ domain that foster vascular amyloid accumulation. Unlike the $\beta$ - and $\gamma$ - cleavage site mutations used to boost $A \beta$ production or shift the $42: 40$ ratio without affecting the $A \beta$ sequence itself, these internal mutations change the amino acid sequence of $A \beta$. The mutations most often used in this manner were identified from kindreds in the Netherlands (Dutch, A $\beta$ E22Q $[12,13]$ ), Arctic (Arc, A $\beta$ E22G $[14,15]$ ), and Iowa (A $\beta$ D23N [16]).

In all cases, whether APP modifications are introduced through an over-expressed transgene or via targeted modification of the endogenous allele (knock-in, Table 2), 
Table 1 Standard Transgenic Lines for APP, APP + PS1, and Tau

\begin{tabular}{|c|c|c|c|c|}
\hline Model & Transgene & Transgenic promoter & Availability & Reference \\
\hline \multicolumn{5}{|l|}{ APP Transgenics } \\
\hline PDAPP & huAPP $_{770}$ (Ind) minigene (cDNA + introns 6-8) & PDGFB & Novartis & [2] \\
\hline $\operatorname{Tg} 2576$ & huAPP $_{695}$ (Swe) & hamster Prnp & Taconic, Charles River & [95] \\
\hline C3-3 & mo/huAPP 695 (Swe) & mouse Prnp & MMRRC 34828-JAX & [96] \\
\hline APP23 & huAPP $_{751}$ (Swe) & mouse Thy 1 & JAX 030504 & [100] \\
\hline$J 20$ & huAPP $_{770}($ Swe/Ind) minigene (cDNA + introns 6-8) & PDGFB & MMRRC 34836-JAX & [54] \\
\hline TgCRND8 & huAPP $_{695}($ Swe/Ind) & hamster Prnp & Peter St. George-Hyslop & [51] \\
\hline Tg-SwDI & huAPP $_{770}$ (Swe/Dutch/lowa) & mouse Thy 1 & MMRRC 34843-JAX & [210] \\
\hline \multicolumn{5}{|l|}{ APP/PS1 Transgenics } \\
\hline APP/PS1 Line 85 & mo/huAPP 695 (Swe); Tg huPSEN1 ( $\Delta$ E9) & mouse Prnp & MMRRC 34832-JAX, 34,829-JAX & [99] \\
\hline APPPS1 & huAPP $_{695}$ (Swe); huPSEN1 (L166P) & mouse Thy 1 & Mathias Jucker & [211] \\
\hline 5XFAD Tg6799 & huAPP $_{695}$ (Swe/Flo/Lon); huPSEN1 (M146 L/L286 V) & mouse Thy 1.2 & MMRRC 34840-JAX, 34,848-JAX & [47] \\
\hline \multicolumn{5}{|l|}{ Tau Transgenics } \\
\hline Tau Tg Line 43 & huMAPT $_{3 R O N}(w t)$ & mouse Prnp & JAX 003741 & [212] \\
\hline JNPL3 & hUMAPT $_{4 R O N}(\mathrm{P} 301 \mathrm{~L})$ & mouse Prnp & Taconic & [34] \\
\hline hTau.P301S & hUMAPT $_{4 R O N}(\mathrm{P} 301 \mathrm{~S})$ & mouse Thy1.2 & Michel Goedert & [213] \\
\hline PS19 & hUMAPT $_{4 R 1 N}(\mathrm{P} 301 \mathrm{~S})$ & mouse Prnp & JAX 008169 & [33] \\
\hline \multicolumn{5}{|c|}{ APP/PS1/Tau Transgenic } \\
\hline $3 \times T g-A D$ & huAPP $_{695}$ (Swe); MAPT 4 RoN $(\mathrm{P} 301 \mathrm{~L}) ;$ Psen $^{\mathrm{M} 146 \mathrm{~V}}$ knock-in & mouse Thy 1.2 & MMRRC 34830-JAX & [101] \\
\hline
\end{tabular}

Tables 1-4: Refer to Fig. 1 for illustration of APP mutations.

the amino acid sequence of $A \beta$ itself is almost always converted from mouse to human by 3 amino acid substitutions at $A \beta$ residues G5R, F10Y and R13H. BACE1 processes murine APP at the +11 rather than +1 site of $A \beta$ [17]. As a result of this shift, mouse $A \beta 11-40 / 42$ does not aggregate in vivo [18]. Simply humanizing the $A \beta$ sequence yields full-length $1-40 / 42$ peptide which readily aggregates in a time- and concentration-dependent manner to produce amyloid deposits.

The amyloid plaques and CAA produced by genetic modification of APP in mice share many characteristics of the human neuropathology, but important distinctions exist. These distinctions have been recently reviewed and are therefore not covered here in any detail [19]. Generally speaking, most APP modified mice develop both diffuse and fibrillar $A \beta$ deposits that can be distinguished by comparing silver staining or $A \beta$ immunohistochemistry against Congo red or thioflavin-S histology. Fibrillar plaques are often surrounded by reactive astrocytes and microglia and by dystrophic neurites (axonal swellings). Synapse loss can be observed in the zone immediately adjacent to fibrillar deposits and several models display mild neuron loss with age, but none develop the severe atrophy observed in human AD. Some APP models develop modest levels of

Table 2 Lines with physiological expression of APP, PS1, and Tau

\begin{tabular}{|c|c|c|c|c|}
\hline Model & Allele & Targeting approach & Availability & Reference \\
\hline$\overline{A P P^{N L h}}$ & endogenous mouse App with Swe mutation and humanized $A \beta$ domain & Knock-in & NA & [89] \\
\hline APP R1.40 & complete human genomic APP (Swe) & YAC transgenic & MMRRC 34831-JAX & [86] \\
\hline $\mathrm{APP}^{\mathrm{SL}}$ & mouse/human App hybrid with humanized A $\beta$ domain (Swe/Lon) & Knock-in & NA & [92] \\
\hline APPDSL & endogenous mouse App with humanized $A \beta$ domain (Swe/Dutch/Lon) & Knock-in & Hui Zheng & [57] \\
\hline $\begin{array}{l}\text { APP }^{N L}, \text { APP }^{N L F}, \\
\text { and APP }\end{array}$ & $\begin{array}{l}\text { endogenous mouse App with humanized A } \beta \text { domain and (Swe (NL), } \\
\text { Swe/lbe (NLF), or Swe/Arc/lbe (NLGF)) }\end{array}$ & Knock-in & Takaomi Saido & [58] \\
\hline $\mathrm{PS} 1^{\mathrm{M} 146 \mathrm{~V}}$ & endogenous mouse Psen 1 (M146 V) & Knock-in & JAX 004193 & [214] \\
\hline PS1 KI & endogenous mouse Psen1 (P264L) & Knock-in & NA & [215] \\
\hline htau & $\begin{array}{l}\text { complete human genomic MAPT (wt) with targeted disruption of } \\
\text { murine Mapt }\end{array}$ & PAC transgenic $\times$ Mapt $\mathrm{KO}$ & JAX 005491 & [37] \\
\hline
\end{tabular}

Tables 1-4: Refer to Fig. 1 for illustration of APP mutations 
hyper-phosphorylated tau but none develop true neurofibrillary tangles seen in human AD.

\section{Neurofibrillary tangles}

Neurofibrillary tangles (NFTs) composed of aggregated tau protein are a pathological hallmark of $\mathrm{AD}$ and more than 20 other neurodegenerative conditions collectively known as tauopathies. The severity of NFTs correlates better than amyloid plaques with cognitive decline and neurodegeneration in $\mathrm{AD}$ [20]. Under normal physiological conditions, tau is an unstructured axonal protein that binds and stabilizes microtubules [21]. Hyper-phosphorylation and other aberrant post-translational modifications lead to misfolding and dissociation from microtubules. Redistribution of misfolded tau into the soma and apical dendrites generates NFTs; redistribution to distal dendrites yields neuropil threads [22]. NFT pathology progresses in a hierarchical, stereotyped pattern beginning in the transentorhinal cortex, and gradually extending to hippocampus before ultimately reaching other cortical areas. This pathological spreading through synaptically connected regions is the basis of Braak staging in AD [23]. Mounting evidence from cell culture and mouse models supports the cell-to-cell transfer of tau pathology [24].

In humans, tau is expressed as both three-repeat (3R) or four-repeat (4R) isoforms due to alternative splicing of exon 10 in the microtubule-associated protein tau gene (MAPT), however, only $4 \mathrm{R}$ tau is expressed in adult mice. Mutations in $M A P T$ are not found in $\mathrm{AD}$, but instead cause a subtype of frontotemporal lobar degeneration (FTLD), demonstrating that this pathology is sufficient for neurotoxicity and dementia [25]. Both coding and non-coding mutations have been identified; many of these affect MAPT splicing to favor the $4 R$ isoform arguing that the balance of $3 R / 4 R$ is important for neuronal health $[26,27]$. The genetic imbalance associated with these MAPT mutations in FTLD raises the question of whether isoform dysregulation may also underlie sporadic tauopathies such as AD. Based on these genetic findings, multiple transgenic mouse lines have been created to overexpress human $4 \mathrm{R}$ tau containing FTLD mutations. Of these, the two models, rTg4510 and PS19, are most commonly used.

rTg4510 is a bigenic line in which the human 4R tau with the P301L mutation is expressed in forebrain neurons under indirect control of the Camk2a promoter (described in more detail below under "Controllable transgenics"). The mutant tau transgene is expressed at levels $\sim 13$-fold higher than endogenous mouse tau and the mice develop aggressive NFT pathology and neurodegeneration [28, 29]. Pathological forms of phospho-tau can be observed at 2-3 months of age followed by mature tangles in the cortex at 4 months and hippocampus at 5.5 months. The model is based on the tetracycline-transactivator expression system and therefore affords the flexibility of turning the transgene on and off (again, see "Controllable transgenics" section for details); the tau P301L responder line can also be crossed with other transactivator lines, e.g. EC-tTA [30], to drive expression of mutant tau in other parts of the brain [31, 32]. This flexibility comes with a cost: the system requires two transgenes for expression which complicates further genetic crosses.

The PS19 model is a traditional (non-controllable) transgenic line in which the human 4R tau with the P301S mutation is controlled by the mouse prion promoter, resulting in $\sim 5$-fold overexpression compared to the endogenous mouse tau [33]. The tau phenotype is considerably milder than that of rTg4510, with the onset of phospho-tau pathology at $\sim 6$ months. Of note, these mice develop hindlimb paralysis due to transgene expression in spinal cord and die between 10 and 12 months of age depending on the genetic background. As a result, mature, thioflavin-S positive NFTs are rare. These same limitations in neuropathology and early lethality are also seen in the JNPL3 line expressing 4R P301L tau under the mouse prion promoter [34].

Generally speaking, overexpression of mutant tau is required for phospho-tau and NFT pathology to manifest. Contrary to most APP/A $\beta$ models and consistent with human clinicopathology, the tau mice exhibit age-dependent neurodegeneration in addition to synaptic and cognitive deficits, suggesting that misfolded and/or aggregated tau is directly neurotoxic. The onset and severity of pathology largely correlate with the level of transgene overexpression and the mutation used. Both the rTg4510 and PS19 mice are suitable models for testing the pathological consequences of tau accumulation. Due to its early onset, rTg4510 serves as a good model to test manipulations expected to ameliorate pathology but not those expected to accelerate; the PS19 model can be used for both purposes. The PS19 mice have also been widely used to model "tau transmission" by inoculating either purified tau fibrils or brain lysates from tauopathy patients or tau transgenic mice, and tracking the appearance of phosphotau in synaptically connected regions over time $[35,36]$.

While the tau transgenic models have been successful in modeling NFT pathology and functional impairment, it is important to recognize their shortcomings. First, since no tau mutations have been linked to $\mathrm{AD}$, these mice should be considered models of FTLD, not AD. Second, the transgenic mice express tau cDNA and do not afford modulation of alternative splicing and 3R/4R ratio. Finally, ectopic expression of transgenic tau may not recapitulate the natural evolution of NFT spreading through synaptically connected regions. The htau mice described below overcome these limitations.

Duff, Davies and colleagues created a humanized tau (htau) model by expressing wild-type human MAPT genomic DNA on a mouse Mapt knockout background [37]. These mice preserve the native human $3 R / 4 R$ ratio and were initially described to show insoluble, hyper- 
phosphorylated tau by $\sim 9$ months of age with spatiotemporal progression resembling early stages of human AD. The htau mice also developed age-dependent synaptic and behavioral deficits as well as neuronal loss [38]. These features make htau an attractive model that is pathophysiology relevant to AD. Nevertheless, some important caveats should be noted. The behavioral and neurodegenerative phenotypes appear to be very mild and may not be readily reproducible $[39,40]$. Although not verified, it is suspected that the increasingly delayed and mild phenotypes observed since the model was first introduced may result from shortening of the transgene array over generations of breeding, informally known as 'copy dropping'. The mild phenotype necessitates testing at advanced ages, with the attendant complications in variability, lethality, and cost. Finally, the presence of two alleles (human $M A P T$ transgene and mouse Mapt deletion) complicates additional genetic manipulation.

\section{Neurodegeneration}

The strongest models of AD-related neurodegeneration come from transgenic overexpression of MAPT mutations associated with FTLD. In particular, the rTg4510 model expressing P301L tau develops severe forebrain atrophy, losing up to $40 \%$ of gross brain weight and $>65 \%$ of CA 1 pyramidal neurons by 5.5 months of age [28, 29, 41]. Significant forebrain atrophy with loss of cortical and hippocampal volumes is also observed in the P301S tau model PS19 at advanced ages [33]. In both of these tau models, neuronal loss outside of the hippocampus also observed. Where quantified for the rTg4510 model, neuron loss in cortex begins later than in hippocampus but still reached $>50 \%$ by 8.5 months [41]. Even the htau model overexpressing wild-type human MAPT was initially described with notable neuronal loss, albeit at much later ages ( 17 months) [42], and may have since waned with successive generations of breeding (see "Neurofibrillary tangles" section for more detail).

Only four models of amyloid pathology have shown any substantial degree of neuronal loss, and none of the APP mutations produce the same degree of neurodegeneration in mice that is observed in humans. The first APP mutation model described with neuronal loss was APP23, in which the number of hippocampal CA1 pyramidal cells decreased $14-25 \%$ by $14-18$ months of age, commensurate with plaque load [43]. Neuronal loss was specific for the hippocampus, however, and neuron counts were unchanged in the neocortex of this model [44]. The second model found to develop significant neuronal loss was an intercross between transgenic $\mathrm{APP}^{\mathrm{Swe} / \mathrm{Lon}}$ and PS1 ${ }^{\mathrm{M} 146 \mathrm{~L}}$ lines, which displayed $\sim 25 \%$ loss of CA1 pyramidal neurons by 17 months of age [45]. The same group described even greater loss of CA1 neurons in a second APP $x$ PS1 model later that year [46]. This latter model combined 4
FAD mutations (APP Swe + Lon and PS1 M233 T + L235P) to evoke $\sim 50 \%$ loss of CA1 neurons by 10 months of age. Intriguingly, cell death was again specific to CA1 hippocampal neurons with no net decline in either CA3 or dentate gyrus. The most recent and perhaps most widely used amyloid-based model in which neuronal loss has been described is the 5XFAD line. This mouse is named for its incorporation of 5 distinct $\mathrm{AD}$ mutations into a single transgenic line (APP Swe + Flo + Lon and PS1 M146 L + L286 V), which collectively produce rapid amyloid pathology as early as 2 months of age [47]. Neuron loss has been qualitatively described in the subiculum by 9 months of age; in the neocortex, non-biased stereological estimates suggest that 5 XFAD mice lose $25-40 \%$ of layer 5 pyramidal neurons between 9 and 12 months of age [48, 49]. Neuron loss has not been described in other cortical layers, and despite the marked decrease in layer 5 neurons, the mice show no change in the total number of cortical neurons [48]. This outcome is consistent with the absence of overt brain atrophy in this and other models of $A \beta$ amyloidosis.

\section{Cognitive impairment}

A surprising number and variety of mouse AD models develop some form of cognitive impairment. Where they have been tested, nearly all models of $A \beta$ overproduction based on transgenic APP overexpression show deficits in spatial learning and memory (reviewed in [50]). In many but not all APP models, the onset of cognitive decline occurs in close proximity to that of amyloid deposition, such as in the CRND8 model [51], but has been identified both months prior to pathology in the $\operatorname{Tg} 2576$ model $[52,53]$ and months afterwards in the 5XFAD [47] and tet-off APP models (Chiang et al., in press). Of note, the age and disease stage at which cognitive deficits are observed depends in part on the task being used. This is well illustrated by behavioral characterization of the J20 model: this line shows initial plaque onset by 6 months of age [54], but when tested at 12-16 months performed as well as age-matched controls in the Y-maze and contextual fear conditioning despite showing severe impairment in a cheeseboard test of spatial memory [55].

Even knock-in models based on modification of the endogenous App sequence alone or in addition to mutation of Psen1 can develop learning and memory impairment with age (i.e., homozygote $\mathrm{APP}^{\mathrm{NLh}} / \mathrm{PS}^{\mathrm{P} 264 \mathrm{~L}}$ [56] or $\mathrm{APP}^{\mathrm{NLh}} / \mathrm{PS}^{\mathrm{M} 146 \mathrm{~V}}[39,57]$. Perhaps to an even greater extent for knock-in models than for transgenics, both age and task can influence the reproducibility and robustness of cognitive phenotypes. This caveat is especially poignant when considering the newest set of APP knock-in models (i.e., $\mathrm{APP}^{\mathrm{NL}}, \mathrm{APP}^{\mathrm{NLF}}$, and $\mathrm{APP}^{\mathrm{NLGF}}$ ) where behavioral deficits in the same mouse line have varied between laboratories [58]. Using automated IntelliCage testing equipment, Masuda et al. detected only mild deficits in learning, recall, 
attention, and cognitive flexibility for all but the most aggressive homozygote $\mathrm{APP}^{\mathrm{NLGF}}$ line [59]. However, a follow up study of the APP ${ }^{\mathrm{NLGF}}$ model detected changes in locomotor/exploratory activity, but not learning and memory, despite widespread amyloid deposition [60]. This example serves as a good reminder to check that the model you intend to study has a phenotype in the outcome you intend to measure.

Models of neurofibrillary pathology also show varying degrees of cognitive impairment depending on age, task, and transgene. Like the amyloid models, the tau transgenic lines with more aggressive pathological phenotypes also tend to show more pronounced cognitive changes. The aggressive $\operatorname{rTg} 4510$ model develops progressive worsening in spatial memory that parallels the onset of tau hyper-phosphorylation and neuron loss [28, 29]. Similar deficits, although not as clearly progressive in nature, have been reported for the PS19 tau model [61-63]. Learning and memory impairments are less consistent for tau models with milder pathological phenotypes. For example, the htau model expressing human wild-type tau on a mouse tau null background was initially reported to show age-related decline in spatial learning and object recognition memory [38], however, more recent studies have not reproduced these deficits $[39,40,64]$. Variable cognitive impairment has also been reported for the JNPL3 mouse which expresses near-endogenous levels of P301L tau $[65,66]$. Our ability to detect progressive learning and memory impairment in mice is limited by both the sensitivity and the range of the behavioral tasks we have available. The take home message may be that the chances of observing consistent and reproducible changes in cognitive function against which to gage effects of therapeutic intervention or genetic manipulation are increased by choosing a model that develops substantial $A D$ pathology, regardless of whether this comes in the form of plaques or tangles.

\section{Yin and yang of mouse models: Deciding between transgenics and knock-ins}

After deciding what experimental question you want to address and which phenotype your model must recapitulate to answer that question, you must next decide whether a transgenic mouse line will suffice or if a knock-in model is needed. The central difference between these two approaches is the pattern of protein expression used to induce disease phenotype. In standard transgenic lines, a synthetic cDNA often encoding a disease-associated mutation is controlled by a heterologous promoter that results in an artificial expression pattern of limited spatial and temporal fidelity to the endogenous gene. In knock-in models, the native expression pattern is fully preserved but the protein now contains a disease-associated mutation (i.e., $\mathrm{APP}^{\text {Swe }}$ ) or human-specific variant (i.e., APOEع4). Standard transgenics typically involve biased overexpression of a single splice variant, while knock-ins preserve native splicing at physiological levels. While it is intuitively preferable to use a model that most closely approaches endogenous expression patterns, there are situations where this is not possible or appropriate and where a transgenic model would do better, particularly in driving robust disease pathology. Knowing which compromises can be tolerated is just as important as knowing which may confound your experimental outcome.

There are many cases where the artificial expression of a single disease-associated protein variant may be the most efficient or only way to produce a phenotype in mice. Currently, overexpression of mutant human $4 R$ tau is the only approach that has succeeded in generating thioflavin- and silver-positive neurofibrillary tangles in mice $[29,33]$. Interventions to slow tangle formation therefore often accept the compromise between the presence of pathology and the artificial means by which it was produced (for example, [63, 67]). The use of transgenic models is also a reasonable compromise in studies testing cell nonautonomous effects of protein aggregation, where the cells under study are essentially wild-type (for example, [68]).

In contrast, transgenic overexpression can be problematic for studies where the effects of artificial temporal or spatial expression confound the outcome. For example, we found that transgenic APP expression under control of the Camk2a promoter caused persistent locomotor hyperactivity that prevented accurate cognitive testing [69]. The effect was traced to a consequence of transgenic APP on circuit development when we found that delaying transgene expression until adulthood was sufficient to abate the locomotor phenotype [70]. The same neurodevelopmental interaction also produced cortical hyper-synchrony in young adult APP mice that could again be abated by delaying transgene onset [71]. Although we found a workaround that met our needs, the emergence of knock-in models preserving the endogenous pattern of APP expression would avoid this confound entirely.

Another factor to bear in mind is that the endogenous proteins overexpressed in transgenic models have physiological functions independent of their role in Alzheimer's pathology. For example, overexpression of APP increases the production of soluble APP (N-terminal) fragments, membrane-associated C-terminal fragments, and the cytoplasmic APP intracellular domain (AICD) in addition to $\mathrm{A} \beta$. Endogenous APP and its fragments contribute to cellular adhesion, neurite outgrowth, synapse formation, neuronal survival, and intracellular signaling [72-75]. Thus it is conceivable and perhaps likely that some of the phenotypes observed in APP transgenic mice arise from over-activation of these innate functions [76]. Along with the differences in spatiotemporal expression, elevated levels of these APP fragments may account for some of the reported distinctions between transgenic and knock-in models. The same concerns will also apply to tau transgenic models, where 
overexpression of a single isoform also creates an imbalance of the endogenous splice variants.

Reassuringly, several disease-relevant phenotypes identified in APP transgenic animals have been reproduced in knock-in models, including $A \beta$ plaque formation, microglial and astrocytic activation, loss of synaptic markers, impaired hippocampal neurogenesis and diminished gamma frequency oscillations [58, 76-79]. Other features, such as calpain activation, show less agreement between transgenic and knock-in mice [80]. Of note, cognitive impairment that has been described in numerous APP transgenic models [50] has been more variable in knockin models, albeit far less well studied [56, 58-60]. Phenotypic agreement and discrepancies are also found in the comparison of tau transgenic mice with the htau model which is currently the nearest available to a true knock-in. Admittedly, the comparison between transgenic tau mice expressing mutant variants and htau mice expressing wild-type protein is less apt than for APP models where both transgenics and knock-ins carry FAD mutations. Nevertheless, multiple phenotypes identified in tau transgenic models have also been reported in the htau mouse, including tau hyper-phosphorylation [37, 39, 42, 81-83], diminished neuronal integrity and plasticity [38, 84, 85] and elevated tau kinase activity [42]. Disparities between tau transgenics and the htau model are also observed, most notably in the extent of neurodegeneration, gliosis, and cognitive decline which are quite limited and/or absent even in aged htau animals [39, 40, 81], but see [38, 42].

Taken together, the best approach to mitigate against outcomes arising from the compromises inherent in transgenic models is to test the same outcome in multiple complementary lines. Because the cost of animal studies often renders this impractical, a reasonable alternative might be to choose the model with closest construct validity to the human disease that recapitulates the phenotype under investigation. Perhaps it is easier said than done, but where possible, use models that maintain endogenous protein expression patterns, where not, recognize the caveats that necessarily attend any interpretation of the resulting data.

\section{Factors to bear in mind with knock-in models}

While the bulk of early work to model $\mathrm{AD}$ in mice was done by standard transgenesis, a parallel thrust in the field sought to build models which avoided ectopic overexpression and maintained native transcript variation. The earliest of these models introduced the entire human APP or MAPT genes and their regulatory elements into mice via yeast or P1derived artificial chromosomes (YAC or PAC vectors, respectively) [86-88]. While these models achieved native expression patterns and isoform usage, they shared with traditional transgenic mice the potential for endogenous gene disruption by random chromosomal integration. In addition, the murine App or Mapt gene retains expression and may interfere with the human transgene. Evidence for such a cross-species interaction emerged during construction of the htau model where hyper-phosphorylated tau was only observed once the human MAPT PAC mice were placed on a Mapt null background [37]. Due to the nearendogenous expression level, the APP YAC mice only develop measurable $A \beta$ pathology when a FAD mutation is included (i.e., Swe) and the transgene is bred to homozygosity. Despite their benefit in construct validity, the mild phenotypes and complicated genetic crosses have limited use of the APP YAC and htau models.

An alternative strategy to achieve physiological expression is the knock-in (KI) approach, which is used to modify selected genes without perturbing off-target genomic perturbations. Multiple App and Psen 1 KI lines have been created, but no Mapt lines have been reported to date (Table 2). The first APP KI line, APP ${ }^{\mathrm{NLh}}$, reported in 1996 humanized the $A \beta$ sequence and introduced the Swedish mutation into the mouse App gene [89]. Despite these modifications, the $\mathrm{APP}^{\mathrm{NLh}}$ model did not develop $\mathrm{A} \beta$ pathology or other overt anomalies until interbred with the PS1 ${ }^{\mathrm{P} 264 \mathrm{~L}}$ knock-in line to produce amyloid deposits, synaptic impairments, and altered hippocampal neurogenesis [79, 90, 91]. Additional App knock-in lines have since been created testing various FAD mutations in an effort to promote $\mathrm{A} \beta$ pathology. These include $\mathrm{APP}^{\mathrm{SL}}$ expressing the Swedish and London mutations [92], APP ${ }^{\mathrm{DSL}}$ expressing the Swe, Lon, and Dutch mutations [57], and the recent allelic series from Saido and colleagues expressing the Swe $\left(\mathrm{APP}^{\mathrm{NL}}\right)$, Swe and Beyreuther/Ibe $\left(\mathrm{APP}^{\mathrm{NLF}}\right)$, or Swe, Arc, and Ibe mutations (APP ${ }^{\mathrm{NLGF}}$ ) [58], all with a humanized $\mathrm{A} \beta$ domain. Like the original $\mathrm{APP}^{\mathrm{NLh}}$ model, homozygous $\mathrm{APP}^{\mathrm{SL}}$ and $\mathrm{APP}^{\mathrm{DSL}}$ mice failed to develop A $\beta$ pathology unless interbred with Psen 1 mutant mice. However, unlike the $\mathrm{APP}^{\mathrm{NLh}}$ and $\mathrm{APP}^{\mathrm{SL}}$ models, addition of the Dutch mutation in the APP ${ }^{\mathrm{DSL}}$ mice promoted formation of vascular amyloid characteristic of cerebral amyloid angiopathy (CAA), with cerebral blood flow reduction, late-onset microhemorrhage, and cognitive impairment but only when intercrossed with a Psen 1 mutant line [57].

Unlike the Lon mutation, the Ibe mutation is sufficient to produce $A \beta$ deposition when combined with the Swe mutation in homozygous $\mathrm{APP}^{\mathrm{NLF}}$ knock-in mice; addition of the Arctic mutation in APP ${ }^{\mathrm{NLGF}}$ mice accelerates this phenotype [58]. These models take advantage of the exceptionally high A 342 production afforded by the Beyreuther/Ibe mutation to generate pathology in the absence of Psen 1 mutation. Indeed, the A $\beta 42 / 40$ ratio was 30 -fold higher than under physiological conditions. Similar to other amyloid models, homozygous APP ${ }^{\mathrm{NLF}}$ and APP ${ }^{\mathrm{NLGF}}$ mice develop age-dependent loss of synaptic markers and reactive gliosis, but show more limited behavioral phenotypes (see "Cognitive impairment" section for details) $[58,59]$. 
Overall, the App knock-in models provide precise genetic manipulation and faithful physiological expression of target genes. Achieving this physiological fidelity necessitates several genetic compromises for amyloid pathology to manifest. For example, all amyloid-forming knock-in mice carry multiple FAD mutations and in most cases must be bred to homozygosity to elicit $A \beta$ pathology. Additionally, several earlier $A p p$ knock-in lines required homozygous expression of mutant Psen 1 alleles to obtain amyloid deposition $\left(\mathrm{APP}^{\mathrm{NLh}}, \mathrm{APP}^{\mathrm{SL}}\right.$ and $\mathrm{APP}^{\mathrm{DSL}}$ ), while others do so through supra-physiological production of $\mathrm{A} \beta 42$ (APP $^{\mathrm{NLF}}$ and $\left.\mathrm{APP}{ }^{\mathrm{NLGF}}\right)$. It is also important to note that the Dutch and Arctic mutations used in the APP ${ }^{\mathrm{DSL}}$ and $A P P^{N L G F}$ mice change the primary sequence of $A \beta$ to influence its biophysical properties $[15,93]$. These technical and biological issues should be taken into consideration when deciding whether a knock-in model is best for your experimental needs, and if so, which line to use.

\section{Technical considerations for transgenic models}

To an even greater degree than for knock-in models, multiple design factors go into creating each transgenic line and should be considered when choosing a model for study. The central disease feature to be examined, be it plaques, tangles, degeneration, or cognitive decline, will determine which class of models to consider, but within that class, the best model may depend on a variety of other factors such as where and when critical features of disease will appear. Simply put, the best model isn't always the one you can get from the lab down the hall.

\section{The transcript itself}

Most transgenic constructs are based on artificial cDNAs designed to express a single transcript out of many that are produced by alternative splicing of the endogenous gene. One example of this is the frequent use of the 695 amino acid isoform of APP, the shortest of three alternatively spliced variants (along with 751 and 770 [73]). Because the 695 isoform is predominantly or perhaps exclusively expressed in neurons and accounts for most APP in the brain [94], its use in transgenic constructs intended to increase $A \beta$ production in the brain has been a logical strategy in many cases (i.e., Tg2576 [95], C3-3 [96], and TgCRND8 [51]). Another approach taken in some early transgenic models was to create an APP minigene containing all 18 exons and capable of producing the three main isoforms of 695, 751, and 770 amino acids (i.e., PDAPP [2, 97], and J20 [54]). Both approaches have yielded amyloid pathology in the mouse brain.

Most tau transgenic models have also been constructed using cDNA derived from just one of the six transcripts for human $M A P T$. Several tau models incorporate a familial mutation from FTLD located in the alternatively spliced exon 10 and therefore produce only $4 \mathrm{R}$ tau protein rather than a mixture of $3 R$ and $4 R$ tau (i.e., rTg4510 [29] and PS19 [33]). In an effort to overcome the artificial bias introduced by transgenic production of a single tau isoform, Duff and colleagues used a plasmid artificial chromosome (PAC) to introduce the entire human wild-type MAPT gene and upstream regulatory sequence into the mouse (i.e., Line $8 \mathrm{c}$ [87]). These mice produce all 6 isoforms of human tau at levels several-fold higher than endogenous, but do not develop pathological hyper-phosphorylation unless murine tau is eliminated [37]. In the case of $A D$, it is known that both $3 \mathrm{R}$ and $4 \mathrm{R}$ tau protein contribute to pathologic aggregates [98], but the success of $4 R$ transgenic models suggests that this disease phenotype can be reasonably modeled using just one transcript. In other experimental settings, native transcript variation is required. The nature of the experimental question will dictate whether models based on a single transcript are an acceptable substitute in each case.

\section{The transgenic promoter}

Historically, the promoter elements used in transgenic constructs were chosen to ensure robust, widespread, life-long expression of ectopic protein. Several common promoter constructs have been used over the years, including prion protein (Prnp, i.e., Tg2576 [95], TgCRND8 [51], APP/PS1 Line 85 [99], JNPL3 [34], and PS19 [33]), platelet-derived growth factor $\mathrm{B}$ chain (PDGFB, i.e., PDAPP [2] and J20 [54]), and thymus cell surface antigen 1 (Thy1, i.e., APP23 [100], 5XFAD [47], and 3xTg-AD [101]). While these three promoters induce strong and persistent transgene expression in neurons, PDGFB and Prnp are also active to a lesser extent in non-neuronal cells of the CNS [102], and all three promoters elicit expression in multiple organs outside of the nervous system including heart and liver [103-105]. All three promoters are active in the embryonic brain [103, $105,106]$, and in the adult may be expressed in multiple neuronal subtypes [107-112]. Although these promoters were chosen for strong persistent expression in adult neurons, none of the three is restricted to the CNS and all are active embryonically. If the experimental question at hand requires a more selective temporal or spatial expression pattern, alternative genetic strategies such as the controllable systems described below will be needed to achieve this specificity.

\section{Strain background}

In the past, most transgenes were made using hybrid mouse strains such as C3B6 (APP/PS1 Line 85 [99, 113] and PS19 [33]), B6D2 (J20 [54]) or B6SJL (Tg2576 [95]). The push towards congenic strain backgrounds lead to many lines being backcrossed onto a single parental strain, revealing the impact that genetic context could have on transgene-associated phenotypes. Early work on the Tg2576 model revealed that the transgene was well tolerated on the original hybrid background but caused 
early lethality when backcrossed to C57BL/6 [114]. By the fourth generation, none of transgenic offspring survived past 2.5 months of age. Other $\mathrm{APP}^{\mathrm{Swe}}$ transgenic lines have since been backcrossed to C57BL/6 for $>10$ generations without loss (i.e., APP/PS1 Line 85, C3-3, and J20), suggesting that this strain is not inherently problematic for $\mathrm{AD}$ models and that the premature lethality of Tg2576 likely arose from a specific interaction between the genomic integration site and genetic modifiers of the background strain. Later work using the YAC transgenic model R1.40 demonstrated that genetic background could influence both APP processing and the age at which amyloid deposits appeared, dramatically delaying onset from 13.5 months on C57BL/ 6 to $>20$ months on DBA/2 [115]. These two background strains also influenced phenotype in the APP/PS1 line 85 mice, where the DBA/2 background substantially increased susceptibility to lethal seizures compared to C57BL/6 [116]. Multiple genetic loci may contribute to these strain differences [117], including the kinesin light chain-1 gene identified as a modifier of amyloid onset in the DBA/2 background [118]. As these studies demonstrate, the genetic context in which any transgene acts can significantly influence the resulting phenotype. Several transgenic models are available on multiple inbred and hybrid backgrounds (5XFAD, APP/PS1 Line 85, $\mathrm{Tg} 2576)$, and it is worth investing some time into weighing the options between experimental needs and known characteristics of each strain (i.e., $\mathrm{FVB} / \mathrm{N}$ breed well but are blind as adults; C57BL/6 mice breed less well but are a reasonable option for cognitive testing, etc.).

\section{Age of onset}

The age at which disease-associated phenotypes first appear in each model results from a complex mixture of the strength of the transgene promoter, the aggressiveness of familial mutations included in the transgene, the number of transgene copies incorporated into the insertion site, the chromosomal location of transgene integration, and the genetic background on which the transgene is expressed. The design of the transgene construct likely has the greatest impact on the level at which the transgene is expressed and thus on the age at which phenotypes appear, however, chromosomal integration site and copy number also have substantial influence and cannot (usually) be controlled. As an example of how these latter factors can affect onset, TgCRND8 and C3-3 models both express APP ${ }^{\text {Swe }}$ under control of a prion protein promoter, yet amyloid pathology appears by 2 months of age in TgCRND8 but not until 18 months in C3-3 [51, 119]. If the experimental manipulation is predicted to delay pathogenesis, then an early onset model may be most appropriate. Conversely, if acceleration is anticipated, a late onset model would be better. Bear in mind, however, that while the early onset models may be faster to study, they also create a disconnect between chronological age and pathological condition that does not accurately reflect the aging physiology under which most $\mathrm{AD}$ will occur.

\section{Animal source}

Although it is easy and inexpensive to obtain transgenic models from a lab down the hall, publically-supported repositories like the Jackson Laboratory (Jax) or the Mutant Mouse Research and Resource Centers (MMRRC) in the US, the RIKEN BioResource Center (BRC) Experimental Animal Division in Japan, and the European Mouse Mutant Archive (EMMA) provide genetic validation of their models that is well worth the added cost. As an example of this, Jax screens all incoming models for the presence of common extraneous alleles (Cre, Flp, neo, tTA, GFP and RFP), often to discover that donating labs have intercrossed the line with another transgenic resulting in mistyped offspring that continue to carry the unrecognized modification. Once identified, these extraneous alleles can be removed before the strain is cryopreserved or expanded for distribution. Moreover, Jax routinely genotypes new mice using a single nucleotide polymorphism (SNP) panel to characterize the strain background and elucidate any uncertainties in the parentage of the donated animals. The stock or strain number of the transgenic line also provides a clear means of identifying which model was tested. Common nomenclature can be muddied by varying abbreviations adopted by different laboratories, therefore the stock number can be a universal identifier easily referenced by other researchers. Finally, by supporting communication with receiving investigators, issues that arise in the field can be verified and shared, as done recently for the 3xTg-AD mice upon learning from the donating investigator that male mice may no longer display the phenotypes initially described for this line, while female animals appear unaffected (https://www.jax.org/strain/004807). Similar reporting from users in the field lead to the identification of transgene copy loss in the J20 strain that was remedied by re-importing the line from the donating laboratory; qPCR is for copy number is now a routine part of colony maintenance for this strain (https:// www.jax.org/strain/006293). This type of unpublished information and quality assurance are invaluable in helping to ensure that research effort and resources yield informative and reproducible outcomes. Don't waste your time or funding on mice that aren't what they're meant to be.

\section{Sex as biological variable}

In general, female mice are more susceptible to plaques and tangles than their male counterparts. Earlier-onset pathology has been consistently noted in females across multiple APP transgenic models, including $\mathrm{Tg} 2576$ [120], APP/PS1 [121, 122], an intercross of $\mathrm{APP}^{\text {Swe }} \mathrm{x}$ $\mathrm{PS1}^{\mathrm{A} 246 \mathrm{E}}$ [123], and 3xTg-AD [124]. Where tested, transgene expression appears similar in male and female APP 
mice [125]; instead the accelerated pathology may be attributable to increased $\beta$-secretase processing in females $[124,126]$. Tau pathology also tends to be more pronounced in female transgenic mice, as noted in the rTg4510 [127] and JNPL3 models [128, 129], albeit not in 3xTg-AD [124, 130]. Perhaps as a result of elevated neuropathology, cognitive impairments are also generally greater in female mice, including Tg2576 [131], APP/PS1 [121], CRND8 [132], APP/TTA [125], 3xTg-AD [130], and rTg4510 models [127]. Females also respond more drastically to environmental stress, developing higher amyloid levels in 5XFAD [133], insoluble and caspase-cleaved tau in a tau P301L model [134]. Not all phenotypes are femalebiased, however, as markers of neuroendocrine aging appeared earlier in male than female 3xTg-AD mice [135]. While sex-based differences in pathological phenotypes are not found in every model and are not consistent even for a single feature across all lines, there is accumulating evidence that it can make a difference and should be considered when designing experiments and measuring outcomes. The NIH has made a strong case for greater attention to sex as a biological variable in all basic and translational research, and it is clearly an important factor to consider for $\mathrm{AD}$ where gender clearly contributes to risk [136].

\section{Alternative approaches for transgene expression - viral gene delivery}

While genetically engineered mice are the most common animal models for $\mathrm{AD}$, viral-mediated gene expression systems have been increasingly used to elicit neuropathology either alone or in conjunction with existing genetic models. Two viral systems have been employed for gene expression in rodent brains: lentivirus and adeno-associated virus (AAV). While both systems deliver localized gene expression when stereotaxically injected to the adult brain, AAV can also be used to achieve widespread gene expression when injected into the neonatal brain. There are at least 13 different AAV serotypes with varying tropism. Of these AAV serotypes 1, 2, 6, 8, 9, and 10 have been demonstrated to drive neuronal expression of target genes. Table 3 summarizes the viral models of $A \beta$ and tau pathology created using wild-type rat and mouse.

Viral expression of APP has not yielded much success in producing robust amyloid pathology. Out of a series of amyloid-based expression vectors injected into the hippocampus of adult rats $\left(\mathrm{A} \beta 40, \mathrm{~A} \beta 42\right.$, and $\left.\mathrm{APP}^{\mathrm{Swe}}\right)$, amyloid deposits were only detected in animals receiving A $\beta 42$ virus (i.e., BRI-A $\beta 42$ [137]). By incorporating multiple FAD mutations into APP (Swe/Lon/Aus), Koukouli et al. achieved AD-like amyloid deposits, microgliosis, and reactive astrogliosis 12 months after AAV injection into the prefrontal cortex of adult mice, along with NFT pathology [138].
Compared to the dearth of amyloid viral transgenics displaying AD-like pathology, considerably more tau viral transgenic models have been reported. An exhaustive review of viral tau models has recently been published by Cubinkova et al. and we refer readers to this article for more detailed information [139]. Both lentivirus and AAV have been used to express tau in wild-type mice and rats, and both can generate hyperphosphorylated tau in vivo. Both wild-type and mutant (P301L or P301S) tau have been tested, and both can give rise to pathological hyperphosphorylation, although mutant tau produces a more aggressive phenotype [140]. Mature NFTs have been elusive with viral models unless combined with standard APP transgenics [141] (but see [142]), however, a recent study using neonatal intracerebral ventricular (ICV) injection of AAV1-tau-P301L produced widespread tau hyperphosphorylation in wild-type mice followed by thioflavin-S positive NFTs, suggesting that the onset, duration, or multiplicity of transduction may influence the progression of viral tau pathology [143]. Surprisingly, although the mice exhibited behavioral abnormalities, no neuronal loss was observed.

Viral transgenesis has numerous advantages over traditional transgenic models: 1 ) it is less expensive and faster to generate than germline manipulations; 2) pathology can be regionally targeted, thus allowing analysis of neuronal projections and avoiding peripheral expression; 3) the same virus can often be used in mice or rats, young or old animals, and any region of interest; and 4) viral injection can be combined with genetic models to test functional interactions more quickly and easily than inter-breeding multiple alleles. However, just as with any other system, these benefits come with a cost. First and foremost is mosaicism: not all cells will be transduced, and those that are transduced may take up different numbers of viral particles and express at different levels. This heterogeneity and inter-animal variability necessitates higher animal numbers for each experiment. Second, surgical injection and/or viral transduction may cause an unintended injury response, thus the observed phenotypes may result from an interaction between the expressed viral transgene and the cellular response to injection or transduction. It is therefore important to include a set of animals injected with a control virus encoding a non-pathogenic protein (i.e., GFP or other marker) to confirm that the observed phenotype is transgene-specific. Finally, both AAV and lentivirus are limited in their packaging capacity which prevents the use of large transgenes. For AAV, the maximal transgene size is approximately $4.5 \mathrm{~kb}$, and is not much larger for lentivirus.

\section{Other tools for specific experimental needs - controllable transgenics}

While the first generation transgenic models were useful tools for in vivo studies of protein-protein interactions 
Table 3 Viral transgenic lines for APP and Tau

\begin{tabular}{|c|c|c|c|c|}
\hline Transgene & Promoter & Viral packaging & Host & Reference \\
\hline \multicolumn{5}{|c|}{ Stereotaxically Targeted APP/A $\beta$ Viral Transgenics } \\
\hline BRI-Aß40 BRI-Aß42 & CBA & AAV1 & adult rat & [137] \\
\hline huAPP $_{695}$ (Swe/Lon/Aus) & (human?) EF1A & AAV (serotype not stated) & adult mouse & [138] \\
\hline \multicolumn{5}{|l|}{ Stereotaxically Targeted Tau Viral Transgenics } \\
\hline huMAPT $_{4 R 2 N}(\mathrm{P} 301 \mathrm{~L})$ & CAG & AAV2 & adult rat & [142] \\
\hline huMAPT ${ }_{4 R O N}(\mathrm{P} 301 \mathrm{~S})$ & mouse Pgk & lentivirus & adult mouse & [141] \\
\hline hUMAPT $_{4 R 1 N}(\mathrm{P} 301 \mathrm{~L})$ & CMV & AAV2 & adult mouse & [216] \\
\hline huMAPT $_{4 R 2 N}(\mathrm{P} 301 \mathrm{~L})$ huMAPT $_{4 R 2 N}$ (wt) & human SYN1 & AAV1 & adult mouse & {$[217]$} \\
\hline huMAPT $_{4 R 1 N}(P 301 L)$ hUMAPT $_{4 R 1 N}(w t)$ & CMV & lentivirus & adult rat & [140] \\
\hline huMAPT ${ }_{4 R 2 N}(\mathrm{P} 301 \mathrm{~L})$ & human SYN1 & AAV9 & adult mouse & [218] \\
\hline huMAPT $_{4 \mathrm{RON}}(\mathrm{P} 301 \mathrm{~S}) \mathrm{hUMAPT}_{4 \mathrm{RON}}$ (wt) & mouse Pgk1 & AAV6 & adult mouse & [219] \\
\hline \multicolumn{5}{|l|}{ Whole-Brain Tau Viral Transgenics } \\
\hline huMAPT (P301L) (isoform not stated) & CAG & AAV1 & neonatal mouse & [143] \\
\hline huMAPT 4 4R2N $(P 301 \mathrm{~L})$ & CAG & AAV1 & neonatal mouse & [220] \\
\hline
\end{tabular}

CAG cytomegalovirus immediate early enhancer combined with the chicken $\beta$ actin promoter [209]

$C B A$ chicken $\beta$-actin

$C M V$ cytomegalovirus

Tables 1-4: Refer to Fig. 1 for illustration of APP mutations.

and cellular responses implicated in $\mathrm{AD}$, their design was rigid with no way to modify where or when the disease-associated protein was produced. Questions that required more selective patterns of transgene expression - for example, expression in mature neurons but not neural progenitors - or which required the ability to turn off expression - for example, mimicking the effect of A $\beta$-lowering therapies - lead to the creation of new controllable transgenic models based on the tetracyclinetransactivator (tTA) expression system. In this bi-partite system, tTA acts as an artificial transcription which binds selectively to an artificial DNA promoter sequence known as the tetracycline response element (TRE), both derived from the E. coli operon controlling tetracycline resistance. Co-expression of tTA in mice under a selective promoter (the driver line) with a TRE-dependent transgene (the responder line) produces transcription in a pattern dependent on the transgenic tTA promoter. Because the two transgenes are independent of one another, the same responder line can be mated with various driver lines to produce offspring expressing the same transgene in different cell types. When the tTA protein is exposed to tetracycline or its chemical analogs, it undergoes a conformational change that prevents it from binding DNA. Exposure to tetracycline (or the more commonly used doxycycline (dox)) thus provides temporal control over expression of the responder transgene. Two versions of the tTA have been created and are used under different circumstances. The original tet-off system is based on tTA and as its name implies, is active under basal conditions and arrested upon exposure to dox. The subsequent tet-on system based on the reverse tTA (rtTA) is inactive under basal conditions, and opposite from tTA, causes transcriptional activation upon dox administration.

\section{tTA-expressing driver lines}

Transgene expression with the tet-controlled system requires two parts - a driver line expressing tTA and a responder line expressing the gene of interest under control of a TRE promoter - interbred to yield offspring carrying both alleles. Multiple versions of the TRE promoter have been created (tet $O, P_{\text {TRE }}, P_{\text {TRE3G }}$, etc.), and all work with the two most common versions of tTA (now known as 'first' and 'second' generation transactivators, but originally named tTA [144] and tTA-2 [145]). Although these tet-off transactivators are now considered legacy products by their commercial vendor in favor of increasing signalto-noise improvements in tet-on products, it is the older tet-off system that has been most successful for controllable transgene expression in the mouse brain. Lines expressing tTA or tTA-2 under control of the calcium calmodulin kinase type II $\alpha$ (Camk2a [146]), neurofilament heavy chain (NEFH [147]), and kallikrein related-peptidase 8 promoters (Klk8; also called Prss19 or neuropsin [30]) have been used to direct controllable transgene expression in neuronal subsets of the entorhinal/limbic areas (Klk8), the broader forebrain $(C a m k 2 a)$, or throughout the CNS $(N E F H)$, as needed for the particular experiment (Table 4). The potential for tTA-controlled transgene expression in other cell types was greatly increased by the introduction of two Cre-dependent tTA transgenic lines from Luo, Roos, and colleagues [148, 149]. These 'converter' lines 
Table 4 Controllable transgenic lines for APP and Tau

\begin{tabular}{|c|c|c|c|c|}
\hline Model & Transgene & Promoter & Availability & Reference \\
\hline \multicolumn{5}{|c|}{ tTA-Dependent Responder Lines } \\
\hline $\begin{array}{l}\text { tetO-APP Lines } 102 \\
\text { and } 107\end{array}$ & mo/huAPP 695 (Swe/Ind) & TetO (first generation TRE from pTet-Splice) & MMRRC 34845-JAX, 34846-JAX & [69] \\
\hline rTg4510 & hUMAPT $_{4 R O N}(\mathrm{P} 301 \mathrm{~L})$ & TRE (first generation TRE from pTRE) & JAX 015815, 024854 & [29] \\
\hline rTg21221 & huMAPT $_{4 \text { RON }}(w t)$ & TRE (first generation TRE from pTRE) & Karen Ashe & [156] \\
\hline rTg9191 & huAPP $_{695}$ (Swe/Lon) & TRE (first generation TRE from pTRE) & Karen Ashe & [155] \\
\hline hTau-A152T Line L1 & huMAPT $_{4 R 1 N}(\mathrm{~A} 152 \mathrm{~T})$ & TRE-Tight (second generation TRE) & JAX 028979 & [157] \\
\hline hTau-WT Line L32 & huMAPT $_{4 R 1 N}(w t)$ & TRE-Tight (second generation TRE) & JAX 029269 & [157] \\
\hline \multicolumn{5}{|c|}{ tTA-Expressing Driver Lines } \\
\hline Camk2a-tTA Line B & tTA (first generation) & moCamk2a & JAX 007004, 003010 & [146] \\
\hline EC-tTA & tTA2 (second generation) & Nop/KIk8 & MMRRC 031779-MU & [30] \\
\hline NEFH-tTA Line 8 & tTA (first generation) & human NEFH & JAX 025397 & [147] \\
\hline ROSA:LNL:TTA & optimized/modified tTA (mtTA) & ROSA26-LNL (Cre-dependent) ${ }^{a}$ & JAX 011008 & [148] \\
\hline ROSA26-ZtTA & tTA (first generation) & ROSA26-CAG-LßL (Cre-dependent) ${ }^{b}$ & JAX 012266 (see also 024107) & [149] \\
\hline
\end{tabular}

aNL: loxP-(neomycin/poly A)-loxP

${ }^{b} \mathrm{~L} \beta \mathrm{L}$ : loxP-( $\beta$-geo (lacZ-neomycin phosphotransferase fusion)/3x poly A-loxP

Tables 7-4: Refer to Fig. 1 for illustration of APP mutations.

allow tTA-dependent transgene expression in any cell type for which there is a Cre-specific driver, but has the disadvantage of added breeding to combine three independently assorting alleles (Promoter-Cre $\mathrm{x}$ Cre-dependent [lox-stop-lox]-tTA x TRE-[gene-of-interest]). The flexibility and strength of this approach was nicely demonstrated by the Allen Institute in recent work showing the expression of TRE-dependent transgenes in a variety of neuronal cell types for which only Cre-expressing driver lines exist [150]. This tripartite system maintained the spatial expression pattern imparted by the Cre driver, while gaining the transcriptional amplification provided by tTA.

A number of tet-on (rtTA) driver lines have also been produced but have been generally less successful than tetoff (tTA) lines for CNS expression. Illustrating the difficulty with the tet-on drivers for brain studies, rtTA expression under control of the ubiquitously expressed ROSA 26 promoter or the artificial CAGGS promoter produced strong doxycycline-dependent expression of their respective responder transgenes in peripheral tissue, but neither line achieved transgene expression in the brain $[151,152]$. The lack of brain expression was attributed to relatively poor $\mathrm{CNS}$ permeability of doxycycline required for transcriptional activation with the tet-on system. Indeed, when rtTA has been used for controllable neuronal transgene expression in the brain, doxycycline concentrations up to $30 \times$ higher are needed for transgene expression by the tet-on (rtTA) than for transgene suppression by tet-off (tTA) [153]. More recently, a ubiquitously expressed rtTA controlling PGC1 $\alpha$ was shown to diminish the aggregation of mutant huntingtin protein in the brain of transgenic mice, however, the effect may have been peripherally mediated [154].

\section{TRE-controlled responder lines}

A number of tet-controlled responder lines relevant to AD have been created, characterized, and made available through public repositories. Multiple responder lines are available to express APP harboring dual FAD mutations (APP $^{\text {Swe/Ind }}$ lines 102 and 107 [69] and $\mathrm{APP}^{\text {Swe/Lon }}$ line rTg9191 [155]), while tau models are available to express either wild-type (huMAPT ${ }_{4 \mathrm{RON}}$ line $\mathrm{rTg}_{21221}$ [156] and huMAPT $_{4 \mathrm{R} 1 \mathrm{~N}}$ line L32 [157]) or FTLD-associated variants (huMAPT $^{\mathrm{P} 301 \mathrm{~L}}$ line rTg4510 [29] and huMAPT ${ }^{\mathrm{A} 152 \mathrm{~T}}$ line L1 [157]). Similar to their standard transgenic counterparts, the tet-controlled APP and MAPT strains develop either amyloid plaques or hyper-phosphorylated tau, but can do so on an accelerated timeline compared with traditional models. For example, tetO-APP line 102 used with the Camk2a-tTA driver can develop amyloid plaques by 1-2 months of age (JLJ, unpublished data), while the rTg4510 line (also used with the Camk2a-tTA driver) develops argyrophilic tangles by 4 months and gross forebrain atrophy by 10 months [29]. The aggressiveness of these models is likely due to the high level of transgene expression attained with the tet-transactivator system which can exceed $10 \times$ that of endogenous APP or tau, but is by no means the case for every controllable line.

\section{Transgene suppression with tet-off models}

One of the main reasons for working with the tet-system is the opportunity for temporal control over transgene expression. Doxycycline is commonly used to regulate the system due to better stability than tetracycline; dox has good tissue penetration, is safe for chronic use, and has been well-characterized pharmacologically. Dox can be administered orally via drinking water or chow, with 
several companies offering standard dox chow formulations in addition to custom compounding. The dose required for transgene suppression via tTA is higher than for veterinary therapeutic use: $50-200 \mathrm{ppm}$ in chow comes to roughly $0.15-0.6 \mathrm{mg}$ per day for an adult mouse, while therapeutic use at $2.5-5 \mathrm{mg} / \mathrm{kg}$ PO q12 comes to $0.025-0.05 \mathrm{mg} /$ day [158]. While safe at these doses, doxycycline is not inert: in vitro it can inhibit MMP2 and MMP9 [159, 160] although this effect has not been demonstrated in vivo [161]. More relevant for neurodegeneration studies is the potential anti-inflammatory effect of dox treatment. Where dox has been used as an anti-inflammatory drug, the doses administered are universally higher than used for tTA regulation, in some cases as much as $15 \times$ greater [162-165]. The same trend is true in vitro where dox has been found to dampen cytokine responses by cultured microglial cells, but often at concentrations considerably higher than experienced in vivo [164, 166-168]. Minocycline is a stronger anti-inflammatory than doxycycline, and is more commonly used for its antiinflammatory effect in vivo (for example, see [169-177]). Thus, while there is a potential for inflammatory modulation by dox, it is a considerably weaker agent than minocycline and is usually used in tet-off transgenic models at doses below those shown to suppress microglial function in vivo.

The optimal dose for transgene suppression is influenced by both driver and responder lines and must be determined empirically for each combination. Depending on perdurance of the transgenic protein, maximal suppression is usually attained within days of starting dox treatment [178]. Conversely, the tTA system can be used to activate transgene expression by removing dox from animals reared on the drug [70,147, 178, 179]. This 'reverse' use of dox treatment comes with the risk of diminished transgene expression in animals removed from dox compared with animals never exposed to the drug, especially when treatment is started before transgene expression begins [180] (JLJ unpublished data). Transgene onset after withdrawing dox can be slower than transgene suppression upon dox exposure, and can require up to 2 weeks to reach maximal levels depending on the model and the dosage [181] (JLJ unpublished data). Even under the best conditions, transgene suppression via dox is good but not complete. The TRE controlling the responder transgene contains not only the tet operator sequence that binds tTA but also a minimal CMV promoter to engage transcription. As a result, early versions of TRE-controlled strains produced low levels of transgenic protein even after dox treatment or in the absence of tTA [69, 178, 179]. Later iterations of the TRE have shortened the minimal promoter to reduce transactivator-independent expression (i.e., $P_{\text {TRE3G); }}$; complementary improvements in tTA-2 pared the transcriptional activation domain to limit activity in the presence of dox [145](http://www.tetsystems.com/science- technology/scientific-figures/). Nevertheless, be aware that transgene suppression is not the same as the absence of expression.

\section{The value of tTA controls}

Finally, know that tTA and rtTA are themselves artificial transgenes that should be controlled for in your experimental design. Most common (r)tTA lines were produced by random insertion into the genome and may have disrupted one or more genes in the process. In most cases the insertion site has not been identified, and the possibility of bystander hemizygosity at the disrupted locus should always be considered. In addition, tTA expression may have phenotypic effects of its own. Several groups have reported neurodegenerative phenotypes in tTA-expressing transgenic models, including the heavily used Camk2a-tTA line [182, 183]. In each case, dox-rearing abrogated cell loss, suggesting that the active conformation of tTA and not genome disruption was to blame. Peripheral expression of tTA or rtTA has been linked to lung abnormalities, cardiomyopathy, and microphthalmia independent of any responder transgene [184-186](P. Overbeek, unpublished observation). Inclusion of a tTA-only control group can therefore provide valuable reassurance that observed phenotypes are due to the transgenic protein under study and not to artifacts of this powerful but highly artificial expression system.

\section{Modeling LOAD - incorporating risk alleles for ApoE and TREM2}

Recapitulating amyloid or tau pathology in mice requires the use of dominant mutations identified from rare familial cases of early-onset AD or FTLD. This belies the fact that the vast majority of patients develop late-onset $\mathrm{AD}$ (LOAD) and do not carry mutations in APP, PSEN1 or PSEN2, and that $M A P T$ mutations are not found in $\mathrm{AD}$. Whether these mutation-based, neuropathology-driven models truly capture the key pathological progression of LOAD is an open question. Studies of LOAD have identified multiple genetic factors that influence the risk of AD but which do not directly cause disease. A quarter century ago, Allen Roses and colleagues established the apolipoprotein E $\varepsilon 4$ allele (APOE $\varepsilon 4$ ) as a major susceptibility factor for LOAD [187]; to date ApoEq4 remains the most common and significant risk factor for LOAD. Recent genome-wide association studies have uncovered $>30$ additional risk polymorphisms for LOAD [188]. Collectively, these candidate risk genes suggest that astrocytes, microglia, and immune system dysfunction play a significant role in disease pathogenesis [189]. APOE is normally expressed by astrocytes in the CNS, while another strong modifier, the triggering receptor expressed on myeloid cells 2 (TREM2), is expressed exclusively by microglia in the brain $[190,191]$. The effects of these polymorphisms are an area of active investigation, 
and accordingly, multiple mouse lines of APOE and TREM2 have been created. Modeling of other LOAD genes has been more challenging than for $A P O E$ and TREM2 due to weak individual effect sizes and the location of risk-associated polymorphisms in non-coding regions of the gene.

\section{ApoE}

APOE is an apolipoprotein that binds cholesterol to facilitate its transport. The three APOE isoforms in humans differ at residues 112 and 158: ع2 (Cys 112, Cys158), $\varepsilon 3$ (Cys112, Arg158) and $\varepsilon 4$ (Arg112, Arg158). APOE $\varepsilon 4$ increases AD risk and $\varepsilon 2$ mitigates it. Mouse has only one ApoE isoform and it is believed to resemble human APOE\&3 in its biophysical properties [192]. Mice deficient in ApoE were created by gene targeting nearly 25 years ago [193, 194]. Homozygous ApoE null mice are viable and overtly healthy but develop hypercholesterolemia and atherosclerotic lesions with age (Table 5). Within the CNS, the $A p o E$ null mice display none of the characteristic $\mathrm{AD}$ pathologies, but do have impaired adult hippocampal neurogenesis [195], however, the relevance of this phenotype is unclear. The ApoE knock-out mice have been crossed with various $\mathrm{AD}$ models to test how loss-of-function affects pathology relative to animals expressing one of the three human APOE isoforms (described below).

Three sets of human APOE mice have been generated. The Holtzman group produced transgenic mice expressing human APOEع3 or APOE\&4 cDNA under control of the human GFAP promoter and then removed murine ApoE from the background by crossing the transgenics onto the ApoE null line (line 37 for $\varepsilon 3$ and line 22 for ع4) [196]. The resulting mice express human APOE in the brain at a level similar to that of adult human cortex. While the mice are useful in examining the role of astrocytic APOE and for comparing the effects of $\varepsilon 3$ and $\varepsilon 4$, inherent differences in transgene integration site, copy number, and expression level may confound interpretation of differences between the two isoforms. In addition, the need to maintain each transgene on an ApoE null background for "humanization" of the model makes further genetic studies complicated.

Bruce Lamb's group created APOE $\varepsilon 2, \varepsilon 3$ and $\varepsilon 4$ knock-in mice by targeting human $\varepsilon 2$, $\varepsilon 3$, and $\varepsilon 4$ cDNAs in-frame into the endogenous mouse $A p o E$ gene [197]. Because these mice express human APOE under the endogenous mouse promoter, differences between the APOE isoforms can be accurately compared. An added advantage of this strategy is its direct "humanization" by simultaneously inserting the human allele and disrupting

Table 5 APOE and TREM2 Models

\begin{tabular}{|c|c|c|c|c|}
\hline Model & Allele & Targeting approach & Availability & Reference \\
\hline \multicolumn{5}{|l|}{ ApoE Lines } \\
\hline GFAP-ApoE3 Line 37, GFAP-ApoE4, Line 1 & hUAPOE3 or E4 CDNA & Transgenic, huGFAP promoter & JAX 004633, 004631 & [196] \\
\hline ApoE2, E3, E4 Kl & hUAPOE2, E3, or E4 & Targeted insertion of APOE CDNAs & NA & [197] \\
\hline ApoE KO & $\begin{array}{l}\text { Apoe deletion (exon } 3 \\
\text { replacement) }\end{array}$ & $\begin{array}{l}\text { Targeted neo insertion replacing } \\
\text { part of Apoe exon } 3\end{array}$ & JAX 002052; 014556 & {$[193,221]$} \\
\hline $\mathrm{APOE}^{*} 3, \mathrm{E}^{*} 4 \mathrm{KI}$ & hUAPOE3 or E4 & $\begin{array}{l}\text { Targeted replacement of Apoe } \\
\text { exons 2-4 }\end{array}$ & $\begin{array}{l}\text { JAX } 027894 \text { (E4) } \\
\text { JAX } 029018 \text { (E3) }\end{array}$ & NA \\
\hline APOE2, E3, E4 Targeted replacement & hUAPOE2, E3, or E4 & $\begin{array}{l}\text { Targeted replacement of Apoe } \\
\text { exons 2-4 }\end{array}$ & Taconic & [199-201] \\
\hline \multicolumn{5}{|l|}{ TREM2 Lines } \\
\hline TREM2 KO & $\begin{array}{l}\text { Trem2 deletion (exon } 2-3 \\
\text { deletion) }\end{array}$ & $\begin{array}{l}\text { Targeted lacZ/neo replacement } \\
\text { of TREM2 exons 2-4 }\end{array}$ & UCD/KOMP VG10093 & {$[206]$} \\
\hline TREM2 $2^{-/-}$ & $\begin{array}{l}\text { Trem2 deletion (exon } 2-3 \\
\text { deletion) }\end{array}$ & $\begin{array}{l}\text { Targeted deletion TREM2 exons } \\
3-4\end{array}$ & Marco Colonna & {$[205]$} \\
\hline TREM2 KO & Trem2 deletion (Q17X) & $\begin{array}{l}\text { CRISPR/Cas9 } \\
\text { targeted deletion }\end{array}$ & JAX 027197 & NA \\
\hline TREM2 R47H Kl & endogenous mouse Trem2 (R47H) & $\begin{array}{l}\text { CRISPR/Cas9 } \\
\text { targeted mutation }\end{array}$ & JAX 027918 & NA \\
\hline TREM2 Y38C KI & endogenous mouse Trem2 (Y38C) & $\begin{array}{l}\text { CRISPR/Cas9 } \\
\text { targeted mutation }\end{array}$ & JAX 029725 & NA \\
\hline TREM2 p.T66 M & $\begin{array}{l}\text { endogenous mouse Trem2 } \\
\text { (T66 M) }\end{array}$ & $\begin{array}{l}\text { CRISPR/Cas9 } \\
\text { targeted mutation }\end{array}$ & Christian Haass & [208] \\
\hline TREM2 flox & $\begin{array}{l}\text { Trem } 2^{\text {tm } 1(\text { (EUCOMM }) W t s i} \text { loxP-flanked } \\
\text { mouse Trem2 exons } 2-3\end{array}$ & Targeted insertion & JAX 029853 & NA \\
\hline
\end{tabular}


mouse ApoE. Unfortunately, no isoform-specific differences in brain cholesterol or $A \beta$ levels were detected and the utility of the mice is thus limited.

Through a similar gene-targeting approach, Maeda and colleagues created the so-called APOE targeted-replacement mice in which human $A P O E \varepsilon 2$ [198], $\varepsilon 3$ [199], or $\varepsilon 4$ [200] alleles were inserted into the endogenous mouse $A p o E$ locus (Table 5). Unlike the APOE knock-in series, coding exons 2-4 and the associated intronic sequences of each $A P O E$ gene were used instead of cDNA and mouse $A p o E$ gene was deleted instead of disrupted. These mice exhibit allelespecific differences in both the CNS and periphery and are the most popular APOE mice for testing differential effects of APOE isoforms either on their own or in a model of AD pathology. Although the mice can be purchased through Taconic, there are restrictions on use of the animals. To overcome these limitations, a similar set of APOE-targeted humanization mice was recently created and made available through Jax with few restrictions (APOE*4 KI, Stock No. 027894; APOE*3 KI, Stock No. 029018).
Because the focus of the current review is on practical considerations for best using the models rather than their biological or pathological underpinnings, it will suffice to say that APOE mediates diverse functions in the brain, modifying parenchymal and vascular amyloid pathology, tau-mediated neurodegeneration, and neuroinflammation in an isoform-dependent manner [201-203].

\section{TREM2}

TREM2 is a type- 1 membrane protein expressed in myeloid cells. Autosomal recessive mutations of TREM2 such as Y38C and T66M lead to Nasu-Hakola disease characterized by bone cysts and dementia, believed to arise through loss of function [204]. Rare variants in the TREM2 extracellular domain, particularly R47H, appear to confer LOAD risk in an autosomal dominant manner [190, 191]. The first Trem 2 knock-out strain was created by Colonna and colleagues through targeted deletion of exons 3 and 4 encoding a portion of the transmembrane and cytoplasmic domains [205]. A separate knock-out

Table 6 Quick guide to the pros and cons of commonly used AD mouse models

\begin{tabular}{|c|c|c|c|c|}
\hline Model & Main features & Pros & Cons & $\begin{array}{l}\text { Examples of use } \\
\text { in } A D \text { research }\end{array}$ \\
\hline $\operatorname{Tg} 2576$ & mid-life amyloid pathology (10-14 mo) & $\begin{array}{l}\text { well-characterized, maintains aging } \\
\text { feature of } A D\end{array}$ & $\begin{array}{l}\text { high lethality on C57 background, } \\
\text { Tg male aggressive and needs to } \\
\text { be single-housed }\end{array}$ & {$[222-224]$} \\
\hline APP/PS1 & early-onset ( $\sim 6 \mathrm{mo}$ ) amyloid pathology & $\begin{array}{l}\text { well-characterized, co-integrated } \\
\text { transgenes breed as a single allele }\end{array}$ & $\begin{array}{l}\text { like other co-integrated models, } \\
\text { cannot control for independent } \\
\text { transgene effects }\end{array}$ & {$[225-227]$} \\
\hline 5XFAD & juvenile-onset amyloid pathology ( 3 mo) & $\begin{array}{l}\text { rapid onset phenotype, co-integrated } \\
\text { transgenes breed as a single allele }\end{array}$ & $\begin{array}{l}\text { non-physiological combination of } \\
\text { FAD mutations, marked } \\
\text { intracellular } A \beta \text { accumulation }\end{array}$ & [228-230] \\
\hline $3 \times \operatorname{Tg}-A D$ & $\begin{array}{l}\text { early- to mid-life amyloid pathology plus } \\
\text { hyperphosphorylated tau }\end{array}$ & $\begin{array}{l}\text { captures both } A B \text { and phospho-tau } \\
\text { features of } A D\end{array}$ & $\begin{array}{l}\text { variable pathology between } \\
\text { colonies and sexes, genetic drift } \\
\text { has been observed }\end{array}$ & [231-233] \\
\hline rTg4510 & $\begin{array}{l}\text { early-onset neurofibrillary tangles } \\
(\sim 5-6 \mathrm{mo}) \text {, severe neurodegeneration }\end{array}$ & $\begin{array}{l}\text { temporally controllable, rapid onset } \\
\text { phenotype, develops true NFT } \\
\text { pathology, well-characterized }\end{array}$ & $\begin{array}{l}\text { breeding complicated by need } \\
\text { for two independent transgenes, } \\
13 \text {-fold overexpression of tau } \\
\text { protein }\end{array}$ & {$[67,234,235]$} \\
\hline PS19 & $\begin{array}{l}\text { mid-life neurofibrillary tangles ( } 6-9 \mathrm{mo}) \text {, } \\
\text { marked neurodegeneration }\end{array}$ & $\begin{array}{l}\text { single-transgenic model, mid-life on } \\
\text { set allows use in experiments } \\
\text { expected to either delay or } \\
\text { exacerbate pathology }\end{array}$ & $\begin{array}{l}\text { transgene expression in spinal } \\
\text { cord causes paralysis by mid-life }\end{array}$ & [236-238] \\
\hline APP NLF & $\begin{array}{l}\text { mid-life amyloid pathology ( } \sim 12 \text { mo for } \\
\text { homozygote, but note }>24 \text { mo for } \\
\text { heterozygote allele) }\end{array}$ & $\begin{array}{l}\text { endogenous APP level, native human } \\
\text { A } \beta \text { sequence }\end{array}$ & $\begin{array}{l}\text { limited cognitive impairment, } \\
\text { requires homozygous allele for } \\
\text { mid-life onset }\end{array}$ & {$[59,239]$} \\
\hline APP NLGF & $\begin{array}{l}\text { juvenile-onset amyloid pathology } \\
\text { ( } \sim 3-4 \text { mo for homozygote, } \sim 9 \text { mo for } \\
\text { heterozygote) }\end{array}$ & $\begin{array}{l}\text { endogenous APP level, can be used } \\
\text { as heterozygote }\end{array}$ & $\begin{array}{l}\text { non-native } A \beta \text { sequence, mild } \\
\text { cognitive phenotype }\end{array}$ & {$[60,240]$} \\
\hline hTau & mid-life hyperphosphorylated tau ( 6 mo) & $\begin{array}{l}\text { near-endogenous level expression of } \\
\text { all } 6 \text { human wild-type tau isoforms }\end{array}$ & $\begin{array}{l}\text { complicated breeding of } \\
\text { transgene on null background, } \\
\text { mild phenotype variable between } \\
\text { colonies }\end{array}$ & {$[81,82]$} \\
\hline $\begin{array}{l}\text { APOE2, E3, } \\
\text { E4 Targeted } \\
\text { replacement }\end{array}$ & $\begin{array}{l}\text { allele-specific effects on } A \beta \text {, tau, brain } \\
\text { atrophy, and neuroinflammation; both } \\
\text { central and peripheral functions } \\
\text { influenced by allele }\end{array}$ & $\begin{array}{l}\text { widely-studied, expressed at } \\
\text { endogenous levels, mouse ApoE } \\
\text { deleted }\end{array}$ & $\begin{array}{l}\text { cannot distinguish central vs. } \\
\text { peripheral effects; available } \\
\text { through Taconic but with } \\
\text { restrictions on usage }\end{array}$ & {$[201,241]$} \\
\hline
\end{tabular}


line was generated by the UC Davis KnockOut Mouse Project (KOMP) through targeted replacement of exons 2 , 3, and most of 4 with a lacZ reporter and neomycin resistance cassette [206]. While the KOMP Trem2 line has proven to be a true loss-of-function allele, the deletion results in upregulation of Treml1 which may complicate interpretation of resulting phenotypes [207]. In contrast, marginal Treml1 upregulation was detected in the Colonna line or in a new knock-out line from Jax made using CRISPR/Cas9 genome editing to delete a 175 base pair fragment and create a stop codon at amino acid 17 (Jax stock \#027197). Jax has also created a Cre-conditional allele of Trem 2 by flanking exons 2 and 3 with loxP sites, which will allow peripheral vs. central effects of TREM2 to be dissected (Jax stock \#029853). Finally, knock-in lines incorporating the R47H and Y38C (Jax stock \#027918 and 029725) or T66M [208] variants have been generated. These mice will be valuable for investigating pathogenic mechanisms of TREM2 in both LOAD and Nasu-Hakola disease.

\section{Conclusions}

Although the neuropathology of AD had long been established, it was not until the discovery of familial mutations responsible for early-onset FAD and FTLD that mouse models capturing the hallmark features of AD became possible. Since the first amyloid model was published in 1995, many dozen more genetically engineered lines have been described with select aspects of AD neuropathology and downstream behavioral and degenerative phenotypes. It is our hope that this review presents an insightful and unbiased coverage of the pros and cons of the various $\mathrm{AD}$ mouse models as well as the practical considerations for choosing and using these models. To further facilitate the selection process, below we provide a summary for the most commonly used models (Table 6).

Genetics has been and will remain the driving factor in AD mouse model development. While studies of earlyonset cases established the importance of neurons in APP/ $A \beta$ and tau/NFT pathology, more recent LOAD genes suggest a crucial role for non-neuronal cells, particularly microglia, in disease progression. Future studies would do well to consider changes in the immune system alongside those in neuropathology and cognition. Further, since the vast majority of $\mathrm{AD}$ cases arise not from autosomal dominant mutations but through the complex interaction of multiple genetic polymorphisms and environmental risk factors that accrue overtime, future modeling should also shift from single FAD gene targeting to simultaneous manipulation of multiple LOAD genes. With the advent of CRISPR-Cas9 genome editing and with investment from the National Institutes of Health towards resources such as MODEL-AD (https://model-ad.org), we expect major progress in this next phase of AD model development.

\section{Abbreviations}

3R/4R: Three-repeat or four-repeat tau protein; AD: Alzheimer's disease; ApoE: Apolipoprotein E; APP: Amyloid precursor protein; AB: Amyloid $\beta$ peptide; Arc: Arctic (familial APP mutation); Aus: Austrian (familial APP mutation); BACE1: $\beta$-APP cleaving enzyme; CAA: Cerebral amyloid angiopathy; CAG: Cytomegalovirus immediate early enhancer combined with the chicken $\beta$-actin promoter; Camk2a: Calcium calmodulin kinase type Ila; CBA: Chicken $\beta$-actin; CMV: Cytomegalovirus; Dox: Doxycycline; FAD: Familial Alzheimer's disease; Flo: Florida (familial APP mutation);

FTLD: Frontotemporal lobar degeneration; Ibe: Iberian (familial APP mutation); Ind: Indiana (familial APP mutation); Jax: The Jackson Laboratory; KI: Knock-in; Klk8: Kallikrein related-peptidase 8; KOMP: KnockOut Mouse Project; LOAD: Late-onset Alzheimer's disease; Lon: London (familial APP mutation); MAPT: Microtubule-associated protein tau; NEFH: Neurofilament heavy chain; NFT: Neurofibrillary tangle; PAC: P1-derived artificial chromosome; PDGFB: Platelet-derived growth factor B chain; Prnp: Prion protein; PSEN1 (or PS1): Presenilin 1; rtTA: Reverse tetracycline transactivator; Swe: Swedish (familial APP mutation); Thy1: Thymus cell surface antigen 1; TRE: Tetracycline response element; tTA: Tetracycline transactivator; TREM2: Triggering receptor expressed on myeloid cells 2; YAC: Yeast artificial chromosome

\section{Acknowledgements}

NA

Funding

This work was supported by NIH grants AG058188, AG056028, AG054160, and NS092615 (Jப) and AG020670, AG032051, AG054111, and NS093652 (HZ).

Availability of data and materials

All data generated and analyzed for this review is included in this published article or in the referenced cited.

\section{Authors' contributions}

$J \sqcup$ and $\mathrm{HZ}$ both wrote, edited, and approved the final version of the manuscript.

Ethics approval and consent to participate

NA

Consent for publication

NA

\section{Competing interests}

The authors declare that they have no competing interests.

\section{Publisher's Note}

Springer Nature remains neutral with regard to jurisdictional claims in published maps and institutional affiliations.

\section{Author details}

${ }^{1}$ Department of Neuroscience, Baylor College of Medicine, Houston, TX 77030, USA. ${ }^{2}$ Department of Neurology, Baylor College of Medicine, Houston, TX 77030, USA. ${ }^{3}$ Department of Neurosurgery, Baylor College of Medicine, Houston, TX 77030, USA. ํDepartment of Molecular and Cellular Biology, Baylor College of Medicine, Houston, TX 77030, USA. ${ }^{5}$ Huffington Center on Aging, Baylor College of Medicine, Houston, TX 77030, USA. ${ }^{6}$ Department of Molecular and Human Genetics, Baylor College of Medicine, Houston, TX 77030, USA.

Received: 24 November 2017 Accepted: 7 December 2017

Published online: 22 December 2017

\section{References}

1. Goate A, Chartier-Harlin MC, Mullan M, Brown J, Crawford F, Fidani L, Giuffra $L$, Haynes A, Irving N, James L, et al. Segregation of a missense mutation in the amyloid precursor protein gene with familial Alzheimer's disease. Nature. 1991;349:704-6.

2. Games D, Adams D, Alessandrini R, Barbour R, Berthelette P, Blackwell C, Carr T, Clemens J, Donaldson T, Gillespie F, et al. Alzheimer-type neuropathology in transgenic mice overexpressing V717F beta-amyloid precursor protein. Nature. 1995;373:523-7. 
3. Mullan M, Crawford F, Axelman K, Houlden H, Lilius L, Winblad B, Lannfelt L. A pathogenic mutation for probable Alzheimer's disease in the APP gene at the N-terminus of beta-amyloid. Nat Genet. 1992;1:345-7.

4. Citron M, Oltersdorf T, Haass C, McConlogue L, Hung AY, Seubert P, VigoPelfrey C, Lieberburg I, Selkoe DJ. Mutation of the beta-amyloid precursor protein in familial Alzheimer's disease increases beta-protein production. Nature. 1992;360:672-4.

5. Murrell J, Farlow M, Ghett B, Benson MD. A mutation in the amyloid precursor protein associated with heridtary Alzheimer's disease. Science. 1991:254:97-9.

6. Eckman CB, Mehta ND, Crook R, Perez-tur J, Prihar G, Pfeiffer E, Graff-Radford $\mathrm{N}$, Hinder $\mathrm{P}$, Yager D, Zenk B, et al. A new pathogenic mutation in the APP gene (1716V) increases the relative proportion of a beta 42(43). Hum Mol Genet. 1997;6:2087-9.

7. Guerreiro RJ, Baquero M, Blesa R, Boada M, Bras JM, Bullido MJ, Calado A, Crook R, Ferreira C, Frank A, et al. Genetic screening of Alzheimer's disease genes in Iberian and African samples yields novel mutations in presenilins and APP. Neurobiol Aging. 2010;31:725-31.

8. Sherrington R, Rogaev El, Liang Y, Rogaeva EA, Levesque $G$, Ikeda $M, C h i ~ H$, Lin C, Li G, Holman K, et al. Cloning of a gene bearing missense mutations in early-onset familial Alzheimer's disease. Nature. 1995;375:754-60.

9. Alzheimer's Disease Collaborative $\mathrm{G}$. The structure of the presenilin 1 (S182) gene and identification of six novel mutations in early onset AD families. Nat Genet. 1995;11:219-22

10. Moehlmann T, Winkler E, Xia X, Edbauer D, Murrell J, Capell A, Kaether C, Zheng H, Ghetti B, Haass C, Steiner H. Presenilin-1 mutations of leucine 166 equally affect the generation of the notch and APP intracellular domains independent of their effect on Abeta 42 production. Proc Natl Acad Sci U S A. 2002;99:8025-30.

11. Perez-Tur J, Froelich S, Prihar G, Crook R, Baker M, Duff K, Wragg M, Busfield F, Lendon C, Clark RF, et al. A mutation in Alzheimer's disease destroying a splice acceptor site in the presenilin-1 gene. Neuroreport. 1995;7:297-301.

12. Van Broeckhoven C, Haan J, Bakker E, Hardy JA, Van Hul W, Wehnert A, Vegter-van der Vlis M, Roos RA. Amyloid beta protein precursor gene and hereditary cerebral hemorrhage with amyloidosis (Dutch). Science. 1990;248: 1120-2.

13. Levy E, Carman MD, Fernandez-Madrid IJ, Power MD, Lieberburg I, van Duinen SG, Bots GT, Luyendijk W, Frangione B. Mutation of the Alzheimer's disease amyloid gene in hereditary cerebral hemorrhage, Dutch type. Science. 1990;248:1124-6.

14. Kamino K, Orr HT, Payami H, Wijsman EM, Alonso ME, Pulst SM, Anderson L, O'Dahl S, Nemens E, White JA, et al. Linkage and mutational analysis of familial Alzheimer disease kindreds for the APP gene region. Am J Hum Genet. 1992;51:998-1014.

15. Nilsberth C, Westlind-Danielsson A, Eckman CB, Condron MM, Axelman K, Forsell C, Stenh C, Luthman J, Teplow DB, Younkin SG, et al. The 'Arctic' APP mutation (E693G) causes Alzheimer's disease by enhanced Abeta protofibril formation. Nat Neurosci. 2001;4:887-93.

16. Grabowski TJ, Cho HS, Vonsattel JP, Rebeck GW, Greenberg SM. Novel amyloid precursor protein mutation in an lowa family with dementia and severe cerebral amyloid angiopathy. Ann Neurol. 2001;49:697-705.

17. Cai H, Wang Y, McCarthy D, Wen H, Borchelt DR, Price DL, Wong PC. BACE1 is the major beta-secretase for generation of Abeta peptides by neurons. Nat Neurosci. 2001:4:233-4.

18. Xu G, Ran Y, Fromholt SE, Fu C, Yachnis AT, Golde TE, Borchelt DR. Murine Abeta over-production produces diffuse and compact Alzheimer-type amyloid deposits. Acta Neuropathol Commun. 2015;3:72.

19. Drummond E, Wisniewski T. Alzheimer's disease: experimental models and reality. Acta Neuropathol. 2017;133:155-75.

20. Giannakopoulos P, Herrmann FR, Bussiere T, Bouras C, Kovari E, Perl DP, Morrison JH, Gold G, Hof PR. Tangle and neuron numbers, but not amyloid load, predict cognitive status in Alzheimer's disease. Neurology. 2003;60: 1495-500.

21. Mandelkow EM, Mandelkow E. Biochemistry and cell biology of tau protein in neurofibrillary degeneration. Cold Spring Harb. Perspect. Med. 2012;2:a006247.

22. Lee VM, Goedert M, Trojanowski JQ. Neurodegenerative tauopathies. Annu Rev Neurosci. 2001;24:1121-59.

23. Braak H, Braak E. Staging of Alzheimer's disease-related neurofibrillary changes. Neurobiol Aging. 1995;16:271-8. discussion 278-284

24. Goedert M, Eisenberg DS, Crowther RA. Propagation of tau aggregates and Neurodegeneration. Annu Rev Neurosci. 2017;40:189-210.
25. Gendron TF, Petrucelli $L$. The role of tau in neurodegeneration. Mol Neurodegener. 2009;4:13.

26. Hong M, Zhukareva V, Vogelsberg-Ragaglia V, Wszolek Z, Reed L, Miller BI, Geschwind DH, Bird TD, McKeel D, Goate A, et al. Mutation-specific functional impairments in distinct tau isoforms of hereditary FTDP-17. Science. 1998:282:1914-7.

27. Hutton M, Lendon CL, Rizzu P, Baker M, Froelich S, Houlden H, PickeringBrown S, Chakraverty S, Isaacs A, Grover A, et al. Association of missense and 5'-splice-site mutations in tau with the inherited dementia FTDP-17. Nature. 1998;393:702-5.

28. Ramsden M, Kotilinek L, Forster C, Paulson J, McGowan E, SantaCruz K, Guimaraes A, Yue M, Lewis J, Carlson G, et al. Age-dependent neurofibrillary tangle formation, neuron loss, and memory impairment in a mouse model of human tauopathy (P301L). J Neurosci. 2005;25:10637-47.

29. SantaCruz K, Lewis J, Spires T, Paulson J, Kotilinek L, Ingelsson M, Guimaraes A, DeTure M, Ramsden M, McGowan E, et al. Tau suppression in a neurodegenerative mouse model improves memory function. Science. 2005;309:476-81.

30. Yasuda M, Johnson-Venkatesh EM, Zhang H, Parent JM, Sutton MA, Umemori $\mathrm{H}$. Multiple forms of activity-dependent competition refine hippocampal circuits in vivo. Neuron. 2011;70:1128-42.

31. Liu L, Drouet V, Wu JW, Witter MP, Small SA, Clelland C, Duff K. Transsynaptic spread of tau pathology in vivo. PLoS One. 2012;7:e31302.

32. de Calignon A, Polydoro M, Suarez-Calvet M, William C, Adamowicz DH, Kopeikina KJ, Pitstick R, Sahara N, Ashe KH, Carlson GA, et al. Propagation of tau pathology in a model of early Alzheimer's disease. Neuron. 2012;73:685-97.

33. Yoshiyama Y, Higuchi M, Zhang B, Huang SM, Iwata N, Saido TC, Maeda J, Suhara T, Trojanowski JQ, Lee VM. Synapse loss and microglial activation precede tangles in a P301S tauopathy mouse model. Neuron. 2007:53:337-51.

34. Lewis J, McGowan E, Rockwood J, Melrose H, Nacharaju P, Van Slegtenhorst M, Gwinn-Hardy K, Paul Murphy M, Baker M, Yu X, et al. Neurofibrillary tangles, amyotrophy and progressive motor disturbance in mice expressing mutant (P301L) tau protein. Nat Genet. 2000;25:402-5.

35. Iba M, Guo JL, McBride JD, Zhang B, Trojanowski JQ, Lee VM. Synthetic tau fibrils mediate transmission of neurofibrillary tangles in a transgenic mouse model of Alzheimer's-like tauopathy. J Neurosci. 2013;33:1024-37.

36. Holmes BB, Furman JL, Mahan TE, Yamasaki TR, Mirbaha H, Eades WC, Belaygorod L, Cairns NJ, Holtzman DM, Diamond MI. Proteopathic tau seeding predicts tauopathy in vivo. Proc Natl Acad Sci U S A. 2014;111:E4376-85.

37. Andorfer C, Kress Y, Espinoza M, de Silva R, Tucker KL, Barde YA, Duff K, Davies P. Hyperphosphorylation and aggregation of tau in mice expressing normal human tau isoforms. J Neurochem. 2003;86:582-90.

38. Polydoro M, Acker CM, Duff K, Castillo PE, Davies P. Age-dependent impairment of cognitive and synaptic function in the htau mouse model of tau pathology. J Neurosci. 2009;29:10741-9.

39. Guo Q, Li H, Cole AL, Hur JY, Li Y, Zheng H. Modeling Alzheimer's disease in mouse without mutant protein Overexpression: cooperative and independent effects of Abeta and tau. PLoS One. 2013;8:e80706.

40. Yetman MJ, Fowler SW, Jankowsky JL. Humanized tau mice with regionalized Amyloid exhibit behavioral deficits but no pathological interaction. PLoS One. 2016;11:e0153724.

41. Spires TL, Orne JD, SantaCruz K, Pitstick R, Carlson GA, Ashe KH, Hyman BT. Region-specific dissociation of neuronal loss and neurofibrillary pathology in a mouse model of tauopathy. Am J Pathol. 2006;168:1598-607.

42. Andorfer C, Acker CM, Kress Y, Hof PR, Duff K, Davies P. Cell-cycle reentry and cell death in transgenic mice expressing nonmutant human tau isoforms. J Neurosci. 2005;25:5446-54.

43. Calhoun ME, Wiederhold KH, Abramowski D, Phinney AL, Probst A, Sturchler-Pierrat C, Staufenbiel M, Sommer B, Jucker M. Neuron loss in APP transgenic mice. Nature. 1998;395:755-6.

44. Bondolfi L, Calhoun M, Ermini F, Kuhn HG, Wiederhold KH, Walker L, Staufenbiel M, Jucker M. Amyloid-associated neuron loss and gliogenesis in the neocortex of amyloid precursor protein transgenic mice. J Neurosci. 2002;22:515-22.

45. Schmitz C, Rutten BP, Pielen A, Schafer S, Wirths O, Tremp G, Czech C, Blanchard V, Multhaup G, Rezaie P, et al. Hippocampal neuron loss exceeds amyloid plaque load in a transgenic mouse model of Alzheimer's disease. Am J Pathol. 2004;164:1495-502.

46. Casas C, Sergeant N, Itier JM, Blanchard V, Wirths O, van der Kolk N, Vingtdeux V, van de Steeg E, Ret G, Canton T, et al. Massive CA1/2 neuronal loss with intraneuronal and $\mathrm{N}$-terminal truncated Abeta42 accumulation in a novel Alzheimer transgenic model. Am J Pathol. 2004;165:1289-300. 
47. Oakley H, Cole SL, Logan S, Maus E, Shao P, Craft J, Guillozet-Bongaarts A, Ohno M, Disterhoft J, Van Eldik L, et al. Intraneuronal $\beta$-amyloid aggregates, neurodegeneration, and neuron loss in transgenic mice with five famlial alzheimer's disease mutations: potential factors in amyloid plaque formation. J Neurosci. 2006;26:10129-40.

48. Jawhar S, Trawicka A, Jenneckens C, Bayer TA, Wirths O. Motor deficits, neuron loss, and reduced anxiety coinciding with axonal degeneration and intraneuronal Abeta aggregation in the 5XFAD mouse model of Alzheimer's disease. Neurobiol Aging. 2012;33:196 e129-40.

49. Eimer WA, Vassar R. Neuron loss in the 5XFAD mouse model of Alzheimer's disease correlates with intraneuronal Abeta42 accumulation and Caspase-3 activation. Mol Neurodegener. 2013;8:2.

50. Webster SJ, Bachstetter AD, Nelson PT, Schmitt FA, Van Eldik LJ. Using mice to model Alzheimer's dementia: an overview of the clinical disease and the preclinical behavioral changes in 10 mouse models. Front Genet. 2014;5:88.

51. Chishti MA, Yang DS, Janus C, Phinney AL, Horne P, Pearson J, Strome R, Zuker N, Loukides J, French J, et al. Early-onset amyloid deposition and cognitive deficits in transgenic mice expressing a double mutant form of amyloid precursor protein 695. J Biol Chem. 2001;276:21562-70.

52. Lesne S, Koh MT, Kotilinek L, Kayed R, Glabe CG, Yang A, Gallagher M, Ashe $\mathrm{KH}$. A specific amyloid-beta protein assembly in the brain impairs memory. Nature. 2006;440:352-7.

53. Westerman MA, Cooper-Blacketer D, Mariash A, Kotilinek L, Kawarabayashi T, Younkin LH, Carlson GA, Younkin SG, Ashe KH. The relationship between Abeta and memory in the Tg2576 mouse model of Alzheimer's disease. J Neurosci. 2002;22:1858-67.

54. Mucke L, Masliah E, Yu GQ, Mallory M, Rockenstein EM, Tatsuno G, Hu K, Kholodenko D, Johnson-Wood K, McConlogue L. High-level neuronal expression of A-beta 1-42 in wild-type human amyloid protein precursor transgenic mice: synaptotoxicity without plaque formation. J Neurosci. 2000; 20:4050-8.

55. Karl T, Bhatia S, Cheng D, Kim WS, Garner B. Cognitive phenotyping of amyloid precursor protein transgenic J20 mice. Behav Brain Res. 2012;228:392-7.

56. Webster SJ, Bachstetter AD, Van Eldik LJ. Comprehensive behavioral characterization of an APP/PS-1 double knock-in mouse model of Alzheimer's disease. Alzheimers Res Ther. 2013;5:28.

57. Li H, Guo Q, Inoue T, Polito VA, Tabuchi K, Hammer RE, Pautler RG, Taffet $\mathrm{GE}$, Zheng $\mathrm{H}$. Vascular and parenchymal amyloid pathology in an Alzheimer disease knock-in mouse model: interplay with cerebral blood flow. Mol Neurodegener. 2014;9:28.

58. Saito T, Matsuba Y, Mihira N, Takano J, Nilsson P, Itohara S, I wata N, Saido TC. Single app knock-in mouse models of Alzheimer's disease. Nat Neurosci. 2014; 17:661-3.

59. Masuda A, Kobayashi Y, Kogo N, Saito T, Saido TC, Itohara S. Cognitive deficits in single app knock-in mouse models. Neurobiol Learn Mem. 2016;135:73-82.

60. Whyte LS, Hemsley KM, Lau AA, Hassiotis S, Saito T, Saido TC, Hopwood JJ, Sargeant TJ. Reduction in open field activity in the absence of memory deficits in the AppNL-G-F knock-in mouse model of Alzheimer's disease. Behav Brain Res. 2018;336:177-81.

61. Brunden KR, Zhang B, Carroll J, Yao Y, Potuzak JS, Hogan AM, Iba M, James MJ, Xie SX, Ballatore C, et al. Epothilone D improves microtubule density, axonal integrity, and cognition in a transgenic mouse model of tauopathy. J Neurosci. 2010;30:13861-6.

62. Takeuchi H, Iba M, Inoue H, Higuchi M, Takao K, Tsukita K, Karatsu Y, Iwamoto Y, Miyakawa T, Suhara T, et al. P301S mutant human tau transgenic mice manifest early symptoms of human tauopathies with dementia and altered sensorimotor gating. PLoS One. 2011;6:e21050.

63. Zhang B, Carroll J, Trojanowski JQ, Yao Y, Iba M, Potuzak JS, Hogan AM, Xie SX, Ballatore C, Smith AB 3rd, et al. The microtubule-stabilizing agent, epothilone $D$, reduces axonal dysfunction, neurotoxicity, cognitive deficits, and Alzheimerlike pathology in an interventional study with aged tau transgenic mice. J Neurosci. 2012;32:3601-11.

64. Geiszler PC, Barron MR, Pardon MC. Impaired burrowing is the most prominent behavioral deficit of aging htau mice. Neuroscience. 2016;329:98-111.

65. Morgan D, Munireddy S, Alamed J, DeLeon J, Diamond DM, Bickford P, Hutton M, Lewis J, McGowan E, Gordon MN. Apparent behavioral benefits of tau overexpression in P301L tau transgenic mice. J. Alzheimers Dis. 2008;15:605-14.

66. Arendash GW, Lewis J, Leighty RE, McGowan E, Cracchiolo JR, Hutton M, Garcia MF. Multi-metric behavioral comparison of APPsw and P301L models for Alzheimer's disease: linkage of poorer cognitive performance to tau pathology in forebrain. Brain Res. 2004;1012:29-41.
67. Polito VA, Li H, Martini-Stoica H, Wang B, Yang L, Xu Y, Swartzlander DB, Palmieri M, di Ronza A, Lee VM, et al. Selective clearance of aberrant tau proteins and rescue of neurotoxicity by transcription factor EB. EMBO Mol. Med. 2014:6:1142-60.

68. Condello C, Yuan P, Schain A, Grutzendler J. Microglia constitute a barrier that prevents neurotoxic protofibrillar Abeta42 hotspots around plaques. Nat Commun. 2015;6:6176.

69. Jankowsky JL, Slunt HH, Gonzales V, Savonenko AV, Wen JC, Jenkins NA, Copeland NG, Younkin LH, Lester HA, Younkin SG, Borchelt DR. Persistent amyloidosis following suppression of $A \beta$ production in a transgenic model of Alzheimer's disease. PLoS medicine. 2005;2:e355.

70. Rodgers SP, Born HA, Das P, Jankowsky JL. Transgenic APP expression during postnatal development causes persistent locomotor hyperactivity in the adult. Mol Neurodegener. 2012;7:28.

71. Born HA, Kim JY, Savjani RR, Das P, Dabaghian YA, Guo Q, Yoo JW, Schuler $D R$, Cirrito JR, Zheng $H$, et al. Genetic suppression of transgenic APP rescues hypersynchronous network activity in a mouse model of Alzeimer's disease. J Neurosci. 2014;34:3826-40.

72. van der Kant R, Goldstein LS. Cellular functions of the amyloid precursor protein from development to dementia. Dev Cell. 2015;32:502-15.

73. Zheng $\mathrm{H}$, Koo EH. Biology and pathophysiology of the amyloid precursor protein. Mol Neurodegener. 2011;6:27.

74. Dawkins E, Small DH. Insights into the physiological function of the beta-amyloid precursor protein: beyond Alzheimer's disease. J Neurochem. 2014;129:756-69.

75. Muller UC, Deller T, Korte M. Not just amyloid: physiological functions of the amyloid precursor protein family. Nat Rev Neurosci. 2017;18:281-98.

76. Sasaguri H, Nilsson P, Hashimoto S, Nagata K, Saito T, De Strooper B, Hardy J, Vassar R, Winblad B, Saido TC. APP mouse models for Alzheimer's disease preclinical studies. EMBO J. 2017;36:2473-87.

77. Nakazono T, Lam TN, Patel AY, Kitazawa M, Saito T, Saido TC, Igarashi KM. Impaired in vivo gamma oscillations in the medial Entorhinal cortex of knock-in Alzheimer model. Front Syst Neurosci. 2017;11:48.

78. Malthankar-Phatak G, Poplawski S, Toraskar N, Siman R. Combination therapy prevents amyloid-dependent and -independent structural changes. Neurobiol Aging. 2012;33:1273-83.

79. Zhang C, McNeil E, Dressler L, Siman R. Long-lasting impairment in hippocampal neurogenesis associated with amyloid deposition in a knockin mouse model of familial Alzheimer's disease. Exp Neurol. 2007;204:77-87.

80. Saito T, Matsuba Y, Yamazaki N, Hashimoto S, Saido TC. Calpain activation in Alzheimer's model mice is an artifact of APP and Presenilin Overexpression. J Neurosci. 2016;36:9933-6.

81. Bhaskar K, Konerth M, Kokiko-Cochran ON, Cardona A, Ransohoff RM, Lamb BT. Regulation of tau pathology by the microglial fractalkine receptor. Neuron. 2010;68:19-31.

82. Maphis N, Xu G, Kokiko-Cochran ON, Jiang S, Cardona A, Ransohoff RM, Lamb BT, Bhaskar K. Reactive microglia drive tau pathology and contribute to the spreading of pathological tau in the brain. Brain. 2015;138:1738-55.

83. Ojo JO, Mouzon B, Greenberg MB, Bachmeier C, Mullan M, Crawford F. Repetitive mild traumatic brain injury augments tau pathology and glial activation in aged hTau mice. J Neuropathol Exp Neurol. 2013;72:137-51.

84. Alldred MJ, Duff KE, Ginsberg SD. Microarray analysis of CA1 pyramidal neurons in a mouse model of tauopathy reveals progressive synaptic dysfunction. Neurobiol Dis. 2012;45:751-62.

85. Dickstein DL, Brautigam H, Stockton SD Jr, Schmeidler J, Hof PR. Changes in dendritic complexity and spine morphology in transgenic mice expressing human wild-type tau. Brain Struct Funct. 2010;214:161-79.

86. Lamb BT, Call LM, Slunt HH, Bardel KA, Lawler AM, Eckman CB, Younkin SG, Holtz G, Wagner SL, Price DL, et al. Altered metabolism of familial Alzheimer's disease-linked amyloid precursor protein variants in yeast artificial chromosome transgenic mice. Hum Mol Genet. 1997;6:1535-41.

87. Duff K, Knight H, Refolo LM, Sanders S, Yu X, Picciano M, Malester B, Hutton M, Adamson J, Goedert M, et al. Characterization of pathology in transgenic mice over-expressing human genomic and cDNA tau transgenes. Neurobiol Dis. 2000;7:87-98.

88. Lamb BT, Sisodia SS, Lawler AM, Slunt HH, Kitt CA, Kearns WG, Pearson PL, Price DL, Gearhart JD. Introduction and expression of the 400 kilobase amyloid precursor protein gene in transgenic mice [corrected]. Nat Genet. 1993;5:22-30.

89. Reaume AG, Howland DS, Trusko SP, Savage MJ, Lang DM, Greenberg BD, Siman R, Scott RW. Enhanced amyloidogenic processing of the beta-amyloid precursor protein in gene-targeted mice bearing the Swedish familial Alzheimer's disease mutations and a "humanized" Abeta sequence. J Biol Chem. 1996;271:23380-8. 
90. Flood DG, Reaume AG, Dorfman KS, Lin YG, Lang DM, Trusko SP, Savage MJ, Annaert WG, De Strooper B, Siman R, Scott RW. FAD mutant PS-1 genetargeted mice: increased a beta 42 and a beta deposition without APP overproduction. Neurobiol Aging. 2002;23:335-48.

91. Chang EH, Savage MJ, Flood DG, Thomas JM, Levy RB, Mahadomrongkul V, Shirao T, Aoki C, Huerta PT. AMPA receptor downscaling at the onset of Alzheimer's disease pathology in double knockin mice. Proc Natl Acad Sci U S A. 2006:103:3410-5.

92. Kohler C, Ebert U, Baumann K, Schroder H. Alzheimer's disease-like neuropathology of gene-targeted APP-SLXPS1mut mice expressing the amyloid precursor protein at endogenous levels. Neurobiol Dis. 2005; 20:528-40.

93. Tsubuki S, Takaki Y, Saido TC. Dutch, Flemish, Italian, and Arctic mutations of APP and resistance of Abeta to physiologically relevant proteolytic degradation. Lancet. 2003;361:1957-8.

94. Sisodia SS, Koo EH, Hoffman PN, Perry G, Price DL. Identification and transport of full-length amyloid precursor proteins in rat peripheral nervous system. J Neurosci. 1993;13:3136-42.

95. Hsiao K, Chapman P, Nilsen S, Eckman C, Harigaya Y, Younkin S, Yang F, Cole G. Correlative memory deficits, Abeta elevation, and amyloid plaques in transgenic mice. Science. 1996;274:99-102.

96. Borchelt DR, Thinakaran G, Eckman CB, Lee MK, Davenport F, Ratovitsky T, Prada CM, Kim G, Seekins S, Yager D, et al. Familial Alzheimer's diseaselinked presenilin 1 variants elevate Abeta1-42/1-40 ratio in vitro and in vivo. Neuron. 1996;17:1005-13.

97. Rockenstein EM, McConlogue L, Tan H, Power M, Masliah E, Mucke L. Levels and alternative splicing of amyloid beta protein precursor (APP) transcripts in brains of APP transgenic mice and humans with Alzheimer's disease. J Biol Chem. 1995;270:28257-67.

98. Espinoza M, de Silva R, Dickson DW, Davies P. Differential incorporation of tau isoforms in Alzheimer's disease. J. Alzheimers Dis. 2008;14:1-16.

99. Jankowsky JL, Fadale DJ, Anderson J, Xu GM, Gonzales V, Jenkins NA, Copeland NG, Lee MK, Younkin LH, Wagner SL, et al. Mutant presenilins specifically elevate the levels of the 42 residue $\beta$-amyloid peptide in vivo: evidence for augmentation of a 42-specific $\gamma$-secretase. Hum Mol Genet. 2004;13:159-70

100. Sturchler-Pierrat C, Abramowski D, Duke M, Wiederhold KH, Mistl C, Rothacher S, Ledermann B, Burki K, Frey P, Paganetti PA, et al. Two amyloid precursor protein transgenic mouse models with Alzheimer disease-like pathology. Proc Natl Acad Sci U S A. 1997:94:13287-92.

101. Oddo S, Caccamo A, Shepherd JD, Murphy MP, Golde TE, Kayed R, Metherate R, Mattson MP, Akbari Y, LaFerla FM. Triple-transgenic model of Alzheimer's disease with plaques and tangles: intracellular Abeta and synaptic dysfunction. Neuron. 2003;39:409-21.

102. Lesuisse C, Xu G, Anderson J, Wong M, Jankowsky J, Holtz G, Gonzalez V, Wong PC, Price DL, Tang F, et al. Hyper-expression of human apolipoprotein E4 in astroglia and neurons does not enhance amyloid deposition in transgenic mice. Hum Mol Genet. 2001;10:2525-37.

103. Campsall KD, Mazerolle CJ, De Repentingy Y, Kothary R, Wallace VA. Characterization of transgene expression and Cre recombinase activity in a panel of Thy-1 promoter-Cre transgenic mice. Dev. Dyn. 2002;224:135-43.

104. Borchelt DR, Davis J, Fischer M, Lee MK, Slunt HH, Ratovitsky T, Regard J, Copeland NG, Jenkins NA, Sisodia SS, Price DL. A vector for expressing foreign genes in the brains and hearts of transgenic mice. Genet Anal. 1996; 13:159-63.

105. Sasahara M, Fries JW, Raines EW, Gown AM, Westrum LE, Frosch MP, Bonthron DT, Ross R, Collins T. PDGF B-chain in neurons of the central nervous system, posterior pituitary, and in a transgenic model. Cell. 1991;64:217-27.

106. Davis JA, Naruse S, Chen H, Eckman C, Younkin S, Price DL, Borchelt DR, Sisodia SS, Wong PC. An Alzheimer's disease-linked PS1 variant rescues the developmental abnormalities of PS1-deficient embryos. Neuron. 1998;20:603-9.

107. Lee WC, Huang H, Feng G, Sanes JR, Brown EN, So PT, Nedivi E. Dynamic remodeling of dendritic arbors in GABAergic interneurons of adult visual cortex. PLoS Biol. 2006:4:e29.

108. O'Mahony A, Raber J, Montano M, Foehr E, Han V, Lu SM, Kwon H, LeFevour A, Chakraborty-Sett S, Greene WC. NF-kappaB/Rel regulates inhibitory and excitatory neuronal function and synaptic plasticity. Mol Cell Biol. 2006:26:7283-98.

109. van den Pol AN, Ghosh PK, Liu RJ, Li Y, Aghajanian GK, Gao XB. Hypocretin (orexin) enhances neuron activity and cell synchrony in developing mouse GFP-expressing locus coeruleus. J Physiol. 2002;541:169-85.
110. Hantman AW, van den Pol AN, Perl ER. Morphological and physiological features of a set of spinal substantia gelatinosa neurons defined by green fluorescent protein expression. J Neurosci. 2004;24:836-42.

111. Setsuie R, Wang YL, Mochizuki H, Osaka H, Hayakawa H, Ichihara N, Li H, Furuta A, Sano Y, Sun YJ, et al. Dopaminergic neuronal loss in transgenic mice expressing the Parkinson's disease-associated UCH-L1 I93M mutant. Neurochem Int. 2007;50:119-29.

112. Feng G, Mellor RH, Bernstein M, Keller-Peck C, Nguyen QT, Wallace M, Nerbonne JM, Lichtman JW, Sanes JR. Imaging neuronal subsets in transgenic mice expressing multiple spectral variants of GFP. Neuron. 2000;28:41-51.

113. Jankowsky JL, Slunt HH, Ratovitski T, Jenkins NA, Copeland NG, Borchelt DR. Co-expression of multiple transgenes in mouse CNS: a comparison of strategies. Biomol Eng. 2001;17:157-65.

114. Carlson GA, Borchelt DR, Dake A, Turner S, Danielson V, Coffin JD, Eckman C, Meiners J, Nilsen SP, Younkin SG, Hsiao KK. Genetic modification of the phenotypes produced by amyloid precursor protein overexpression in transgenic mice. Hum Mol Genet. 1997;6:1951-9.

115. Lehman EJ, Kulnane LS, Gao Y, Petriello MC, Pimpis KM, Younkin L, Dolios G, Wang R, Younkin SG, Lamb BT. Genetic background regulates beta-amyloid precursor protein processing and beta-amyloid deposition in the mouse. Hum Mol Genet. 2003:12:2949-56.

116. Jackson HM, Onos KD, Pepper KW, Graham LC, Akeson EC, Byers C, Reinholdt LG, Frankel WN, Howell GR. DBA/2J genetic background exacerbates spontaneous lethal seizures but lessens amyloid deposition in a mouse model of Alzheimer's disease. PLoS One. 2015;10:e0125897.

117. Ryman D, Gao Y, Lamb BT. Genetic loci modulating amyloid-beta levels in a mouse model of Alzheimer's disease. Neurobiol Aging. 2008;29:1190-8.

118. Morihara T, Hayashi N, Yokokoji M, Akatsu H, Silverman MA, Kimura N, Sato M, Saito Y, Suzuki T, Yanagida K, et al. Transcriptome analysis of distinct mouse strains reveals kinesin light chain-1 splicing as an amyloid-beta accumulation modifier. Proc Natl Acad Sci U S A. 2014;111:2638-43.

119. Borchelt DR, Ratovitski T, van Lare J, Lee MK, Gonzales V, Jenkins NA, Copeland NG, Price DL, Sisodia SS. Accelerated amyloid deposition in the brains of transgenic mice coexpressing mutant presenilin 1 and amyloid precursor proteins. Neuron. 1997;19:939-45.

120. Callahan MJ, Lipinski WJ, Bian F, Durham RA, Pack A, Walker LC. Augmented senile plaque load in aged female beta-amyloid precursor proteintransgenic mice. Am J Pathol. 2001;158:1173-7.

121. Gallagher JJ, Minogue AM, Lynch MA. Impaired performance of female APP/ PS1 mice in the Morris water maze is coupled with increased Abeta accumulation and microglial activation. Neurodegener Dis. 2013;11:33-41.

122. Jiao SS, Bu XL, Liu YH, Zhu C, Wang QH, Shen LL, Liu CH, Wang YR, Yao XQ, Wang YJ. Sex dimorphism profile of Alzheimer's disease-type pathologies in an APP/PS1 mouse model. Neurotox Res. 2016;29:256-66.

123. Wang J, Tanila H, Puolivali J, Kadish I, van Groen T. Gender differences in the amount and deposition of amyloidbeta in APPswe and PS1 double transgenic mice. Neurobiol Dis. 2003;14:318-27.

124. Hirata-Fukae C, Li HF, Hoe HS, Gray AJ, Minami SS, Hamada K, Niikura T, Hua F, Tsukagoshi-Nagai H, Horikoshi-Sakuraba Y, et al. Females exhibit more extensive amyloid, but not tau, pathology in an Alzheimer transgenic model. Brain Res. 2008;1216:92-103.

125. Melnikova T, Fromholt S, Kim H, Lee D, Xu G, Price A, Moore BD, Golde TE, Felsenstein KM, Savonenko A, Borchelt DR. Reversible pathologic and cognitive phenotypes in an inducible model of Alzheimer-amyloidosis. J Neurosci. 2013;33:3765-79.

126. Schafer S, Wirths O, Multhaup G, Bayer TA. Gender dependent APP processing in a transgenic mouse model of Alzheimer's disease. J Neural Transm (Vienna). 2007;114:387-94.

127. Yue M, Hanna A, Wilson J, Roder H, Janus C. Sex difference in pathology and memory decline in rTg4510 mouse model of tauopathy. Neurobiol Aging. 2011;32:590-603.

128. Asuni AA, Boutajangout A, Quartermain D, Sigurdsson EM. Immunotherapy targeting pathological tau conformers in a tangle mouse model reduces brain pathology with associated functional improvements. J Neurosci. 2007; 27:9115-29.

129. Buccarello L, Grignaschi G, Castaldo AM, Di Giancamillo A, Domeneghini C, Melcangi RC, Borsello T. Sex impact on tau-aggregation and postsynaptic protein levels in the P301L mouse model of Tauopathy. J. Alzheimers Dis. 2017;56:1279-92.

130. Clinton LK, Billings LM, Green KN, Caccamo A, Ngo J, Oddo S, McGaugh JL, LaFerla FM. Age-dependent sexual dimorphism in cognition and stress response in the 3XTg-AD mice. Neurobiol Dis. 2007;28:76-82. 
131. King DL, Arendash GW, Crawford F, Sterk T, Menendez J, Mullan MJ. Progressive and gender-dependent cognitive impairment in the APP(SW) transgenic mouse model for Alzheimer's disease. Behav Brain Res. 1999;103:145-62.

132. Granger MW, Franko B, Taylor MW, Messier C, George-Hyslop PS, Bennett SA. A TgCRND8 mouse model of Alzheimer's disease exhibits sexual dimorphisms in behavioral indices of cognitive reserve. J. Alzheimers Dis. 2016;51:757-73.

133. Devi L, Alldred MJ, Ginsberg SD, Ohno M. Sex- and brain region-specific acceleration of beta-amyloidogenesis following behavioral stress in a mouse model of Alzheimer's disease. Mol Brain. 2010;3:34.

134. Sotiropoulos I, Silva J, Kimura T, Rodrigues AJ, Costa P, Almeida OF, Sousa N, Takashima A. Female hippocampus vulnerability to environmental stress, a precipitating factor in tau aggregation pathology. J. Alzheimers Dis. 2015;43:763-74.

135. Gimenez-Llort L, Arranz L, Mate I, De la Fuente M. Gender-specific neuroimmunoendocrine aging in a triple-transgenic 3xTg-AD mouse model for Alzheimer's disease and its relation with longevity. Neuroimmunomodulation. 2008;15:331-43.

136. Alzheimer'sAssociation. Alzheimer's disease facts and figures. Alzheimers Dement. 2017;2017(13):325-73.

137. Lawlor PA, Bland RJ, Das P, Price RW, Holloway V, Smithson L, Dicker BL, During MJ, Young D, Golde TE. Novel rat Alzheimer's disease models based on AAV-mediated gene transfer to selectively increase hippocampal Abeta levels. Mol Neurodegener. 2007;2:11.

138. Koukouli F, Rooy M, Maskos U. Early and progressive deficit of neuronal activity patterns in a model of local amyloid pathology in mouse prefrontal cortex. Aging (Albany NY). 2016;8:3430-49.

139. Cubinkova V, Valachova B, Brezovakova V, Szabo R, Zimova I, Kostecka Z Jadhav S. Next generation tau models in Alzheimer's disease research - virus based gene delivery systems. Acta Virol. 2017;61:13-21.

140. Caillierez R, Begard S, Lecolle K, Deramecourt V, Zommer N, Dujardin S, Loyens A, Dufour N, Auregan G, Winderickx J, et al. Lentiviral delivery of the human wild-type tau protein mediates a slow and progressive neurodegenerative tau pathology in the rat brain. Mol. Ther. 2013;21:1358-68.

141. Osinde M, Clavaguera F, May-Nass R, Tolnay M, Dev KK. Lentivirus tau (P301S) expression in adult amyloid precursor protein (APP)-transgenic mice leads to tangle formation. Neuropathol Appl Neurobiol. 2008;34:523-31.

142. Klein RL, Lin WL, Dickson DW, Lewis J, Hutton M, Duff K, Meyer EM, King MA. Rapid neurofibrillary tangle formation after localized gene transfer of mutated tau. Am J Pathol. 2004;164:347-53.

143. Cook C, Kang SS, Carlomagno Y, Lin WL, Yue M, Kurti A, Shinohara M, Jansen-West K, Perkerson E, Castanedes-Casey M, et al. Tau deposition drives neuropathological, inflammatory and behavioral abnormalities independently of neuronal loss in a novel mouse model. Hum Mol Genet. 2015;24:6198-212.

144. Furth PA, St Onge L, Boger H, Gruss P, Gossen M, Kistner A, Bujard H, Hennighausen L. Temporal control of gene expression in transgenic mice by a tetracycline-responsive promoter. Proc Natl Acad Sci U S A. 1994;91:9302-6.

145. Urlinger S, Baron U, Thellmann M, Hasan MT, Bujard H, Hillen W. Exploring the sequence space for tetracycline-dependent transcriptional activators: novel mutations yield expanded range and sensitivity. Proc Natl Acad Sci U S A. 2000;97:7963-8.

146. Mayford M, Bach ME, Huang YY, Wang L, Hawkins RD, Kandel ER. Control of memory formation through regulated expression of a CaMKII transgene. Science. 1996;274:1678-83.

147. Walker AK, Spiller KJ, Ge G, Zheng A, Xu Y, Zhou M, Tripathy K, Kwong LK, Trojanowski JQ, Lee VM. Functional recovery in new mouse models of ALS/ FTLD after clearance of pathological cytoplasmic TDP-43. Acta Neuropathol. 2015;130:643-60.

148. Wang L, Sharma K, Deng HX, Siddique T, Grisotti G, Liu E, Roos RP. Restricted expression of mutant SOD1 in spinal motor neurons and interneurons induces motor neuron pathology. Neurobiol Dis. 2008;29:400-8.

149. Li L, Tasic B, Micheva KD, Ivanov VM, Spletter ML, Smith SJ, Luo L. Visualizing the distribution of synapses from individual neurons in the mouse brain. PLoS One. 2010;5:e11503.

150. Madisen L, Garner AR, Shimaoka D, Chuong AS, Klapoetke NC, Li L, van der Bourg A, Niino Y, Egolf L, Monetti C, et al. Transgenic mice for intersectional targeting of neural sensors and effectors with high specificity and performance. Neuron. 2015;85:942-58.

151. Hochedlinger K, Yamada Y, Beard C, Jaenisch R. Ectopic expression of Oct-4 blocks progenitor-cell differentiation and causes dysplasia in epithelial tissues. Cell. 2005;121:465-77.
152. Premsrirut PK, Dow LE, Kim SY, Camiolo M, Malone CD, Miething C, Scuoppo C, Zuber J, Dickins RA, Kogan SC, et al. A rapid and scalable system for studying gene function in mice using conditional RNA interference. Cell. 2011;145:145-58.

153. Yamamoto M, Wada N, Kitabatake Y, Watanabe D, Anzai M, Yokoyama M, Teranishi Y, Nakanishi S. Reversible suppression of glutamatergic neurotransmission of cerebellar granule cells in vivo by genetically manipulated expression of tetanus neurotoxin light chain. J Neurosci. 2003;23:6759-67.

154. Tsunemi T, Ashe TD, Morrison BE, Soriano KR, Au J, Roque RA, Lazarowski ER, Damian VA, Masliah E, La Spada AR. PGC-1alpha rescues Huntington's disease proteotoxicity by preventing oxidative stress and promoting TFEB function. Sci. Transl. Med. 2012;4:142ra197.

155. Liu P, Paulson JB, Forster CL, Shapiro SL, Ashe KH, Zahs KR. Characterization of a novel mouse model of Alzheimer's disease-Amyloid pathology and unique beta-Amyloid Oligomer profile. PLoS One. 2015;10:e0126317.

156. Hoover BR, Reed MN, Su J, Penrod RD, Kotilinek LA, Grant MK, Pitstick R, Carlson GA, Lanier LM, Yuan $L L$, et al. Tau mislocalization to dendritic spines mediates synaptic dysfunction independently of neurodegeneration. Neuron. 2010;68:1067-81.

157. Maeda S, Djukic B, Taneja P, Yu GQ, Lo I, Davis A, Craft R, Guo W, Wang X, Kim $D$, et al. Expression of A152T human tau causes age-dependent neuronal dysfunction and loss in transgenic mice. EMBO Rep. 2016;17:530-51.

158. Carpenter JW, Marion CJ: Exotic animal formulary. 4th edn. St. Louis, Mo.: Elsevier; 2013

159. Golub LM, Lee HM, Ryan ME, Giannobile W, Payne J, Sorsa T. Tetracyclines inhibit connective tissue breakdown by multiple non-antimicrobial mechanisms. Adv Dent Res. 1998;12:12-26.

160. Liu J, Xiong W, Baca-Regen L, Nagase H, Baxter BT. Mechanism of inhibition of matrix metalloproteinase-2 expression by doxycycline in human aortic smooth muscle cells. J Vasc Surg. 2003:38:1376-83.

161. Golledge J, Norman PE, Murphy MP, Dalman RL. Challenges and opportunities in limiting abdominal aortic aneurysm growth. J Vasc Surg. 2017;65:225-33.

162. Yrjanheikki J, Keinanen R, Pellikka M, Hokfelt T, Koistinaho J. Tetracyclines inhibit microglial activation and are neuroprotective in global brain ischemia. Proc Natl Acad Sci U S A. 1998;95:15769-74.

163. Lazzarini M, Martin S, Mitkovski M, Vozari RR, Stuhmer W, Bel ED. Doxycycline restrains glia and confers neuroprotection in a 6-OHDA Parkinson model. Glia. 2013;61:1084-100.

164. Cho Y, Son HJ, Kim EM, Choi JH, Kim ST, Ji IJ, Choi DH, Joh TH, Kim YS, Hwang $\mathrm{O}$. Doxycycline is neuroprotective against nigral dopaminergic degeneration by a dual mechanism involving MMP-3. Neurotox Res. 2009;16:361-71.

165. Zhang GB, Feng $Y H$, Wang $P Q$, Song JH, Wang P, Wang SA. A study on the protective role of doxycycline upon dopaminergic neuron of LPS-PD rat model rat. Eur Rev Med Pharmacol Sci. 2015;19:3468-74.

166. Maezawa I, Zimin PI, Wulff H, Jin LW. Amyloid-beta protein oligomer at low nanomolar concentrations activates microglia and induces microglial neurotoxicity. J Biol Chem. 2011;286:3693-706.

167. Lai AY, Todd KG. Hypoxia-activated microglial mediators of neuronal survival are differentially regulated by tetracyclines. Glia. 2006;53:809-16.

168. Karlsson M, Hammers S, Nilsson-Ehle I, Malmborg AS, Wretlind B. Concentrations of doxycycline and penicillin $\mathrm{G}$ in sera and cerebrospinal fluid of patients treated for neuroborreliosis. Antimicrob Agents Chemother. 1996;40:1104-7.

169. Maier K, Merkler D, Gerber J, Taheri N, Kuhnert AV, Williams SK, Neusch C, Bahr M, Diem R. Multiple neuroprotective mechanisms of minocycline in autoimmune CNS inflammation. Neurobiol Dis. 2007;25:514-25.

170. Peng J, Xie L, Stevenson FF, Melov S, Di Monte DA, Andersen JK. Nigrostriatal dopaminergic neurodegeneration in the weaver mouse is mediated via neuroinflammation and alleviated by minocycline administration. J Neurosci. 2006:26:11644-51.

171. Fan LW, Lin S, Pang Y, Rhodes PG, Cai Z. Minocycline attenuates hypoxiaischemia-induced neurological dysfunction and brain injury in the juvenile rat. Eur J Neurosci. 2006;24:341-50.

172. Hunter CL, Bachman D, Granholm AC. Minocycline prevents cholinergic loss in a mouse model of Down's syndrome. Ann Neurol. 2004;56:675-88.

173. Garwood CJ, Cooper JD, Hanger DP, Noble W. Anti-inflammatory impact of minocycline in a mouse model of tauopathy. Front Psychiatry. 2010;1:136.

174. Hou Y, Ryu CH, Park KY, Kim SM, Jeong CH, Jeun SS. Effective combination of human bone marrow mesenchymal stem cells and minocycline in experimental autoimmune encephalomyelitis mice. Stem Cell Res Ther. 2013;4:77. 
175. Aras M, Urfali B, Serarslan Y, Ozgur T, Ulutas KT, Urfali S, Altas M, Yilmaz N. Protective effects of minocycline against short-term ischemia-reperfusion injury in rat brain. Pediatr Neurosurg. 2013;49:172-8.

176. Chen M, Ona VO, Li M, Ferrante RJ, Fink KB, Zhu S, Bian J, Guo L, Farrell LA, Hersch SM, et al. Minocycline inhibits caspase- 1 and caspase-3 expression and delays mortality in a transgenic mouse model of Huntington disease. Nat Med. 2000;6:797-801.

177. Yrjanheikki J, Tikka T, Keinanen R, Goldsteins G, Chan PH, Koistinaho J. A tetracycline derivative, minocycline, reduces inflammation and protects against focal cerebral ischemia with a wide therapeutic window. Proc Natl Acad Sci U S A. 1999;96:13496-500.

178. Fowler SW, Chiang AC, Savjani RR, Larson ME, Sherman MA, Schuler DR, Cirrito JR, Lesne SE, Jankowsky JL. Genetic modulation of soluble abeta rescues cognitive and synaptic impairment in a mouse model of Alzheimer's disease. J Neurosci. 2014;34:7871-85.

179. Igaz LM, Kwong LK, Lee EB, Chen-Plotkin A, Swanson E, Unger T, Malunda J, Xu Y, Winton MJ, Trojanowski JQ, Lee VM. Dysregulation of the ALSassociated gene TDP-43 leads to neuronal death and degeneration in mice. J Clin Invest. 2011;121:726-38.

180. Bejar R, Yasuda R, Krugers H, Hood K, Mayford M. Transgenic calmodulindependent protein kinase II activation: dose-dependent effects on synaptic plasticity, learning, and memory. J Neurosci. 2002;22:5719-26.

181. Glazewski S, Bejar R, Mayford M, Fox K. The effect of autonomous alphaCaMKII expression on sensory responses and experience-dependent plasticity in mouse barrel cortex. Neuropharmacology. 2001;41:771-8.

182. Barton MD, Dunlop JW, Psaltis G, Kulik J, DeGennaro L, Kwak SP. Modified GFAP promoter auto-regulates tet-activator expression for increased transactivation and reduced tTA-associated toxicity. Brain Res Mol Brain Res. 2002;101:71-81.

183. Han HJ, Allen CC, Buchovecky CM, Yetman MJ, Born HA, Marin MA, Rodgers SP, Song BJ, Lu HC, Justice MJ, et al. Strain background influences neurotoxicity and behavioral abnormalities in mice expressing the tetracycline transactivator. J Neurosci. 2012;32:10574-86.

184. McCloskey DT, Turnbull L, Swigart PM, Zambon AC, Turcato S, Joho S, Grossman W, Conklin BR, Simpson PC, Baker AJ. Cardiac transgenesis with the tetracycline transactivator changes myocardial function and gene expression. Physiol Genomics. 2005;22:118-26.

185. Morimoto M, Kopan R. rtTA toxicity limits the usefulness of the SP-C-rtTA transgenic mouse. Dev Biol. 2009;325:171-8.

186. Sisson TH, Hansen JM, Shah M, Hanson KE, Du M, Ling T, Simon RH, Christensen PJ. Expression of the reverse tetracycline-transactivator gene causes emphysemalike changes in mice. Am J Respir Cell Mol Biol. 2006;34:552-60.

187. Strittmatter WJ, Saunders AM, Schmechel D, Pericak-Vance M, Enghild J, Salvesen GS, Roses AD. Apolipoprotein E: high-avidity binding to betaamyloid and increased frequency of type 4 allele in late-onset familial Alzheimer disease. Proc Natl Acad Sci U S A. 1993;90:1977-81.

188. Karch CM, Goate AM. Alzheimer's disease risk genes and mechanisms of disease pathogenesis. Biol Psychiatry. 2015;77:43-51.

189. Efthymiou AG, Goate AM. Late onset Alzheimer's disease genetics implicates microglial pathways in disease risk. Mol Neurodegener. 2017;12:43.

190. Guerreiro R, Wojtas A, Bras J, Carrasquillo M, Rogaeva E, Majounie E, Cruchaga C, Sassi C, Kauwe JS, Younkin S, et al. TREM2 variants in Alzheimer's disease. N Engl J Med. 2013;368:117-27.

191. Jonsson T, Stefansson H, Steinberg S, Jonsdottir I, Jonsson PV, Snaedal J, Bjornsson S, Huttenlocher J, Levey Al, Lah JJ, et al. Variant of TREM2 associated with the risk of Alzheimer's disease. N Engl J Med. 2013;368:107-16.

192. Chen HK, Liu Z, Meyer-Franke A, Brodbeck J, Miranda RD, McGuire JG, Pleiss MA, Ji ZS, Balestra ME, Walker DW, et al. Small molecule structure correctors abolish detrimental effects of apolipoprotein E4 in cultured neurons. J Biol Chem. 2012;287:5253-66.

193. Piedrahita JA, Zhang SH, Hagaman JR, Oliver PM, Maeda N. Generation of mice carrying a mutant apolipoprotein E gene inactivated by gene targeting in embryonic stem cells. Proc Natl Acad Sci U S A. 1992;89:4471-5.

194. Zhang SH, Reddick RL, Piedrahita JA, Maeda N. Spontaneous hypercholesterolemia and arterial lesions in mice lacking apolipoprotein E. Science. 1992;258:468-71.

195. Yang CP, Gilley JA, Zhang G, Kernie SG. ApoE is required for maintenance of the dentate gyrus neural progenitor pool. Development. 2011;138:4351-62.

196. Sun Y, Wu S, Bu G, Onifade MK, Patel SN, LaDu MJ, Fagan AM, Holtzman DM. Glial fibrillary acidic protein-apolipoprotein $E$ (apoE) transgenic mice: astrocyte-specific expression and differing biological effects of astrocytesecreted apoE3 and apoE4 lipoproteins. J Neurosci. 1998;18:3261-72.
197. Mann KM, Thorngate FE, Katoh-Fukui Y, Hamanaka H, Williams DL, Fujita S, Lamb BT. Independent effects of APOE on cholesterol metabolism and brain Abeta levels in an Alzheimer disease mouse model. Hum Mol Genet. 2004;13:1959-68.

198. Sullivan PM, Mezdour H, Quarfordt SH, Maeda N. Type III hyperlipoproteinemia and spontaneous atherosclerosis in mice resulting from gene replacement of mouse Apoe with human Apoe*2. J Clin Invest. 1998;102:130-5.

199. Sullivan PM, Mezdour H, Aratani Y, Knouff C, Najib J, Reddick RL, Quarfordt SH, Maeda N. Targeted replacement of the mouse apolipoprotein E gene with the common human APOE3 allele enhances diet-induced hypercholesterolemia and atherosclerosis. J Biol Chem. 1997;272:17972-80.

200. Knouff C, Hinsdale ME, Mezdour H, Altenburg MK, Watanabe M, Quarfordt SH, Sullivan PM, Maeda N. Apo E structure determines VLDL clearance and atherosclerosis risk in mice. J Clin Invest. 1999;103:1579-86.

201. Shi Y, Yamada K, Liddelow SA, Smith ST, Zhao L, Luo W, Tsai RM, Spina S, Grinberg LT, Rojas JC, et al. ApoE4 markedly exacerbates tau-mediated neurodegeneration in a mouse model of tauopathy. Nature. 2017:549:523-7.

202. Brendza RP, Bales KR, Paul SM, Holtzman DM. Role of apoE/Abeta interactions in Alzheimer's disease: insights from transgenic mouse models. Mol Psychiatry. 2002;7:132-5.

203. Liu CC, Liu CC, Kanekiyo T, Xu H, Bu G. Apolipoprotein E and Alzheimer disease: risk, mechanisms and therapy. Nat Rev Neurol. 2013;9:106-18.

204. Colonna M. TREMs in the immune system and beyond. Nat Rev Immunol. 2003;3:445-53.

205. Turnbull IR, Gilfillan S, Cella M, Aoshi T, Miller M, Piccio L, Hernandez M, Colonna M. Cutting edge: TREM-2 attenuates macrophage activation. J Immunol. 2006;177:3520-4.

206. Jay TR, Miller CM, Cheng PJ, Graham LC, Bemiller S, Broihier ML, Xu G, Margevicius D, Karlo JC, Sousa GL, et al. TREM2 deficiency eliminates TREM2 + inflammatory macrophages and ameliorates pathology in Alzheimer's disease mouse models. J Exp Med. 2015;212:287-95.

207. Kang SS, Kurti A, Baker KE, Liu CC, Colonna M, Ulrich JD, Holtzman DM, Bu G, Fryer JD. Behavioral and transcriptomic analysis of Trem2-null mice: not all knockout mice are created equal. Hum Mol Genet. 2017;

208. Kleinberger G, Brendel M, Mracsko E, Wefers B, Groeneweg L, Xiang X Focke C, Deussing M, Suarez-Calvet M, Mazaheri F, et al. The FTD-like syndrome causing TREM2 T66M mutation impairs microglia function, brain perfusion, and glucose metabolism. EMBO J. 2017;36:1837-53.

209. Niwa H, Yamamura K, Miyazaki J. Efficient selection for high-expression transfectants with a novel eukaryotic vector. Gene. 1991;108:193-9.

210. Davis J, Xu F, Deane R, Romanov G, Previti ML, Zeigler K, Zlokovic BV, Van Nostrand WE. Early-onset and robust cerebral microvascular accumulation of amyloid beta-protein in transgenic mice expressing low levels of a vasculotropic Dutch/lowa mutant form of amyloid beta-protein precursor. J Biol Chem. 2004;279:20296-306.

211. Radde R, Bolmont T, Kaeser SA, Coomaraswamy J, Lindau D, Stoltze L, Calhoun ME, Jaggi F, Wolburg H, Gengler S, et al. Abeta42-driven cerebral amyloidosis in transgenic mice reveals early and robust pathology. EMBO Rep. 2006;7:940-6.

212. Ishihara T, Hong M, Zhang B, Nakagawa Y, Lee MK, Trojanowski JQ, Lee VM. Age-dependent emergence and progression of a tauopathy in transgenic mice overexpressing the shortest human tau isoform. Neuron. 1999;24:751-62

213. Allen B, Ingram E, Takao M, Smith MJ, Jakes R, Virdee $K$, Yoshida H, Holzer M, Craxton M, Emson PC, et al. Abundant tau filaments and nonapoptotic neurodegeneration in transgenic mice expressing human P301S tau protein. J Neurosci. 2002;22:9340-51.

214. Guo Q, Fu W, Sopher BL, Miller MW, Ware CB, Martin GM, Mattson MP. Increased vulnerability of hippocampal neurons to excitotoxic necrosis in presenilin-1 mutant knock-in mice. Nat Med. 1999;5:101-6.

215. Siman R, Reaume AG, Savage MJ, Trusko S, Lin YG, Scott RW, Flood DG. Presenilin-1 P264L knock-in mutation: differential effects on abeta production, amyloid deposition, and neuronal vulnerability. J Neurosci. 2000;20:8717-26.

216. Ubhi K, Rockenstein E, Doppler E, Mante M, Adame A, Patrick C, Trejo M, Crews L, Paulino A, Moessler H, Masliah E. Neurofibrillary and neurodegenerative pathology in APP-transgenic mice injected with AAV2-mutant TAU: neuroprotective effects of Cerebrolysin. Acta Neuropathol. 2009;117:699-712.

217. Jaworski T, Dewachter I, Lechat B, Croes S, Termont A, Demedts D, Borghgraef P, Devijver H, Filipkowski RK, Kaczmarek L, et al. AAV-tau mediates pyramidal neurodegeneration by cell-cycle re-entry without neurofibrillary tangle formation in wild-type mice. PLoS One. 2009;4:e7280. 
218. Siman R, Lin YG, Malthankar-Phatak G, Dong Y. A rapid gene delivery-based mouse model for early-stage Alzheimer disease-type tauopathy. J Neuropathol Exp Neurol. 2013;72:1062-71.

219. Yang S, Cacquevel M, Saksida LM, Bussey TJ, Schneider BL, Aebischer $P$, Melani R, Pizzorusso T, Fawcett JW, Spillantini MG. Perineuronal net digestion with chondroitinase restores memory in mice with tau pathology. Exp Neurol. 2015;265:48-58.

220. Platt TL, Beckett TL, Kohler K, Niedowicz DM, Murphy MP. Obesity, diabetes, and leptin resistance promote tau pathology in a mouse model of disease. Neuroscience. 2016;315:162-74.

221. Maeda N, Johnson L, Kim S, Hagaman J, Friedman M, Reddick R. Anatomical differences and atherosclerosis in apolipoprotein E-deficient mice with 129/ SvEv and C57BL/6 genetic backgrounds. Atherosclerosis. 2007;195:75-82.

222. Bero AW, Yan P, Roh JH, Cirrito JR, Stewart FR, Raichle ME, Lee JM, Holtzman DM. Neuronal activity regulates the regional vulnerability to amyloid-beta deposition. Nat Neurosci. 2011;14:750-6.

223. Sevigny J, Chiao P, Bussiere T, Weinreb PH, Williams L, Maier M, Dunstan R, Salloway S, Chen T, Ling Y, et al. The antibody aducanumab reduces Abeta plaques in Alzheimer's disease. Nature. 2016;537:50-6.

224. Amar F, Sherman MA, Rush T, Larson M, Boyle G, Chang L, Gotz J, Buisson A, Lesne SE. The amyloid-beta oligomer Abeta*56 induces specific alterations in neuronal signaling that lead to tau phosphorylation and aggregation. Sci Signal. 2017;10

225. Liu CC, Zhao N, Yamaguchi Y, Cirrito JR, Kanekiyo T, Holtzman DM, Bu G. Neuronal heparan sulfates promote amyloid pathology by modulating brain amyloid-beta clearance and aggregation in Alzheimer's disease. Sci. Transl. Med. 2016;8:332ra344.

226. Ofengeim D, Mazzitelli S, Ito Y, DeWitt JP, Mifflin L, Zou C, Das S, Adiconis X, Chen $\mathrm{H}$, Zhu $\mathrm{H}$, et al. RIPK1 mediates a disease-associated microglial response in Alzheimer's disease. Proc Natl Acad Sci U S A. 2017;114:E8788-97.

227. Wojtas AM, Kang SS, Olley BM, Gatherer M, Shinohara M, Lozano PA, Liu CC, Kurti A, Baker KE, Dickson DW, et al. Loss of clusterin shifts amyloid deposition to the cerebrovasculature via disruption of perivascular drainage pathways. Proc Natl Acad Sci U S A. 2017;114:E6962-71.

228. Fu AK, Hung KW, Yuen MY, Zhou X, Mak DS, Chan IC, Cheung TH, Zhang B, Fu WY, Liew FY, Ip NY. IL-33 ameliorates Alzheimer's disease-like pathology and cognitive decline. Proc Natl Acad Sci U S A. 2016;113:E2705-13.

229. laccarino HF, Singer AC, Martorell AJ, Rudenko A, Gao F, Gillingham TZ, Mathys $\mathrm{H}$, Seo J, Kritskiy O, Abdurrob F, et al. Gamma frequency entrainment attenuates amyloid load and modifies microglia. Nature. 2016;540:230-5.

230. Andrew RJ, Fernandez CG, Stanley M, Jiang H, Nguyen P, Rice RC, BuggiaPrevot $\mathrm{V}$, De Rossi P, Vetrivel KS, Lamb R, et al. Lack of BACE1 Spalmitoylation reduces amyloid burden and mitigates memory deficits in transgenic mouse models of Alzheimer's disease. Proc Natl Acad Sci U S A. 2017;114:E9665-74.

231. Caccamo A, Branca C, Talboom JS, Shaw DM, Turner D, Ma L, Messina A, Huang Z, Wu J, Oddo S. Reducing ribosomal protein S6 Kinase 1 expression improves spatial memory and synaptic plasticity in a mouse model of Alzheimer's disease. J Neurosci. 2015;35:14042-56.

232. Mably AJ, Gereke BJ, Jones DT, Colgin LL. Impairments in spatial representations and rhythmic coordination of place cells in the $3 \times \mathrm{Tg}$ mouse model of Alzheimer's disease. Hippocampus. 2017;27:378-92.

233. Zenaro E, Pietronigro E, Della Bianca V, Piacentino G, Marongiu L, Budui S, Turano E, Rossi B, Angiari S, Dusi S, et al. Neutrophils promote Alzheimer's disease-like pathology and cognitive decline via LFA-1 integrin. Nat Med. 2015;21:880-6.

234. Sherman MA, LaCroix M, Amar F, Larson ME, Forster C, Aguzzi A, Bennett DA, Ramsden M, Lesne SE. Soluble conformers of Abeta and tau Alter selective proteins governing axonal transport. J Neurosci. 2016;36:9647-58.

235. Cheng J, Ji D. Rigid firing sequences undermine spatial memory codes in a neurodegenerative mouse model. elife. 2013;2:e00647.

236. Min SW, Chen X, Tracy TE, Li Y, Zhou Y, Wang C, Shirakawa K, Minami SS,

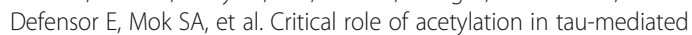
neurodegeneration and cognitive deficits. Nat Med. 2015;21:1154-62.

237. Kaufman SK, Sanders DW, Thomas TL, Ruchinskas AJ, Vaquer-Alicea J, Sharma AM, Miller TM, Diamond MI. Tau Prion strains dictate patterns of cell pathology, progression rate, and regional vulnerability in vivo. Neuron. 2016;92:796-812.

238. Boluda S, Iba M, Zhang B, Raible KM, Lee VM, Trojanowski JQ. Differential induction and spread of tau pathology in young PS19 tau transgenic mice following intracerebral injections of pathological tau from Alzheimer's disease or corticobasal degeneration brains. Acta Neuropathol. 2015;129:221-37.
239. Zhang H, Wu L, Pchitskaya E, Zakharova O, Saito T, Saido T, Bezprozvanny I. Neuronal store-operated calcium entry and mushroom spine loss in Amyloid precursor protein knock-in mouse model of Alzheimer's disease. J Neurosci. 2015:35:13275-86.

240. Hernandez AL, Shah D, Craessaerts K, Saido T, Saito T, De Strooper B, Van der Linden A, D'Hooge R. Subtle behavioral changes and increased prefrontal-hippocampal network synchronicity in APP(NL-G-F) mice before prominent plaque deposition. Behav Brain Res. 2017;

241. Zhao N, Liu CC, Van Ingelgom AJ, Martens YA, Linares C, Knight JA, Painter MM, Sullivan PM, Bu G. Apolipoprotein E4 impairs neuronal insulin signaling by trapping insulin receptor in the Endosomes. Neuron. 2017:96:115-29. e115

\section{Submit your next manuscript to BioMed Central and we will help you at every step:}

- We accept pre-submission inquiries

- Our selector tool helps you to find the most relevant journal

- We provide round the clock customer support

- Convenient online submission

- Thorough peer review

- Inclusion in PubMed and all major indexing services

- Maximum visibility for your research

Submit your manuscript at www.biomedcentral.com/submit
) Biomed Central 